\title{
A földköpeny reológiai kutatása: mennyiségi Fourier transzformációs infravörös spektrometria alkalmazása egy Persány hegységi xenolit példáján
}

\author{
LANGe Thomas Pieter ${ }^{1,2 *}$, SzABÓ Csaba ${ }^{1,3}$, Liptai Nóra ${ }^{2,3}$, PATKó Levente ${ }^{1,2,4}$, Gelencsér Orsolya ${ }^{1,4}$, \\ ARADI László Előd ${ }^{1}$, KovÁcs István János ${ }^{2,3}$ \\ 'Eötvös Loránd Tudományegyetem, Földrajz- és Földtudományi Intézet, Litoszféra Fluidum Kutató Laboratórium (LRG) \\ H-1117, Budapest, Pázmány Péter sétány 1/c, *e-mail: lange.thomas@hotmail.com \\ ${ }^{2}$ MTA CSFK Lendület Pannon LitH Oscope Lendület Kutatócsoport \\ ${ }^{3}$ MTA CSFK Geofizika és Geodéziai Intézet, H-9400, Sopron, Csatkai Endre u. 6-8. \\ ${ }^{4}$ MTA Atommagkutató Intézet, Izotóp Klimatológiai és Környezetkutató Központ (IKER), H-4026, Debrecen, Bem tér 18/c
}

\section{Rheology study on the earth's mantle: Application of quantitative Fourier transform infrared spectroscopyon upper mantle xenolith from the Perşani Mountains}

Abstract

By studying mantle xenoliths we can obtain direct information about the chemical and physical state of the lithospheric mantle. With this information, some important geophysical properties (e.g. seismic velocity, conductivity and effective viscosity) can be calculated, which provide a tool to better understand the evolution of the studied region.

In this paper, we present how even a small amount of 'water' (more precisely structural hydroxyl) in nominally anhydrous minerals (NAMs) can affect the physical properties of the lithospheric mantle and how to quantify the amount of the structural hydroxyl. Fourier transform infrared (FTIR) spectroscopy is a useful technique to study NAMs for their 'water' content, which affects the rheology of the different rock types (e.g. melting temperature, deformation, conductivity). As demonstrated in petrologic experiments $\mathrm{H}^{+}$can be incorporated in a lattice vacancy replacing a cation or incorporate together with another cation, called heteroelectronic incorporation (e.g. $\mathrm{H}^{+}+\mathrm{Al}^{3+}$ or $2 \mathrm{H}^{+}+\mathrm{Ti}^{4+}$ ). When $\mathrm{H}^{+}$ incorporates in a vacancy it binds to an $\mathrm{O}_{2}^{-}$forming a structural hydroxyl $\left(\mathrm{OH}^{-}\right)$group. In some cases, the $\mathrm{OH}^{-}$can bind to $\mathrm{Li}^{+}$or $\mathrm{Na}^{+}$ions within intersticial space. The type of incorporation depends on the composition of the system (e.g. Ti content), the oxygen, $\mathrm{H}_{2} \mathrm{O}$ and $\mathrm{SiO}_{2}$ activity, oxygen fugacity and pressure.

With the help of micro-FTIR one can measure the exact structural hydroxyl content of the nominally anhydrous minerals. This value is defined in ppm wt. or mol\%. Non-polarized micro-FTIR gives a good opportunity to measure small, unoriented grains in a relatively short time compared to the traditional polarized micro-FTIR. The goal of our study is to provide a detailed description of the micro-FTIR method and how it is used to measure structural hydroxyl content in NAMs.

Our study focuses on the lithospheric mantle xenoliths of the Perşani Mountains Volcanic Field and use the results to constrain the physical conditions. Comparing the results with xenoliths from other young volcanic fields (Styrian Basin and Nógrád-Gömör), we have a better understanding of the evolution of the Carpathian-Pannonian region (CPR).

Keywords: FTIR, upper mantle xenolith, geophysics, rheology, Carpathian-Pannonian region, Perşani Mountains

Összefoglalás

A felsőköpenyből származó xenolitok kőzettani és geokémiai vizsgálatával közvetlen ismeretekhez juthatunk a litoszféra fizikai és kémiai állapotáról. Ezen információk birtokában kiszámíthatók a xenolitok által jellemzett köpenylitoszféra legfontosabb geofizikai tulajdonságai (pl. szeizmikus hullámsebesség, fajlagos vezetóképesség, effektív viszkozitás). Ezek a fizikai jellemző́k meghatározók a geofizikai mérések eredményének értelmezésében, és így a kutatott régió geodinamikai fejlődésének megértésében.

Jelen tanulmányban azt mutatjuk be, hogy akár nyomnyi mennyiségú „víz” (helyesebben szerkezeti hidroxil) jelenléte a földköpeny névlegesen vízmentes ásványaiban (röviden NAM elegyrészek az angol „Nominally Anhydrous Minerals" kifejezés alapján) milyen kiemelkedő jelentőséggel bír a litoszféra fizikai viszonyaira, és hogyan reagál a rendszer kémiai összetételére. A felsőköpeny geokémiai és geodinamikai kutatásában alkalmazott spektrometriai technikák közül a Fourier transzformációs infravörös spektrometria (FTIR) a NAM elegyrészek szerkezeti hidroxil-tartalmának tanulmányozásával a kőzetek fizikai viselkedéséről (pl. olvadási hőmérséklet, deformálhatóság, fajlagos vezetőképesség stb.) és bizonyos kémiai tulajdonságairól (H-tartalom) ad képet. Kísérleti kőzettani eredmények alapján a $\mathrm{H}^{+}$töltéskompenzáló kationként vakanciákba önállóan vagy csatolt helyettesítést létrehozva más kationokkal ( $\mathrm{pl}$. $\mathrm{Al}^{3+}$ vagy $\mathrm{Ti}^{4+}$ ) együtt tud a NAM elegyrészekbe beépülni. A vakanciák esetében a $\mathrm{H}^{+}$ valamelyik koordináló oxigénhez csatlakozva $\mathrm{OH}^{-}$(szerkezeti hidroxil) gyököt hoz létre. Ritkán a $\mathrm{H}^{+}$önállóan, intersticiális helyzetben vagy $\mathrm{Li}^{+}$- és $\mathrm{Na}^{+}$-hoz csatlakozva szerkezeti hidroxil formájában is előfordulhat a rácsközi 
térben. A beépülés jellege függ a rendszer összetételétől (pl. Ti-tartalom), az oxigén, $\mathrm{H}_{2} \mathrm{O}$ és $\mathrm{SiO}_{2}$ aktivitásától, az oxigén fugacitástól és a nyomástól.

A beépülés módján kívül a NAM elegyrész pontos szerkezeti hidroxil tartalmát is meg lehet határozni mikro-FTIR spektrometriával. A szerkezeti hidroxil koncentrációt konvencionálisan molekuláris víz egyenértékben és ppm tömegrészben vagy mol\%-ban fejezzük ki. A nem poláros mikro-FTIR módszer térnyerése az utóbbi időben jelentős áttörést hozott, hiszen a kis szemcseméretú $(<0,7 \mathrm{~mm})$ természetes és kísérleti kôzetek ásványainak elemzésére is lehetőség nyílt, amelyre a tradicionálisan megbízhatónak gondolt poláros mikro-FTIR módszer nem adott módot. Tanulmányunk egyik célja, hogy részletes áttekintést adjunk a mikro-FTIR alkalmazásáról a NAM szerkezeti hidroxil tartalmának vizsgálatához.

A nem poláros mikro-FTIR módszert ma már világszerte alkalmazzák, a Kárpát-Pannon régió felsőköpenykutatásában is nagy szerepet kap. Alkalmazását a Persány-hegységi vulkáni terület felsőköpeny xenolitjain mutatjuk be, összehasonlítva korábbi munkákkal a Kárpát-Pannon régióból, kiemelve az eredmények felhasználhatóságát a geofizikai adatok értelmezéséhez és így a Kárpát-Pannon régió geodinamikájának jobb megértéséhez. A persányi-hegységi xenolitra kapott geofizikai eredmények (szeizmikus hullámterjedési sebesség, fajlagos vezetőképesség) és effektív viszkozitás nagy hasonlóságot mutat a Stájer-medence xenolitjaival, ami a két terület hasonló geodinamikai helyzetével függhet össze. A Nógrád-Gömör vulkáni terület xenolitjai eltérő jellemvonásokat mutatnak.

Tárgyszavak: FTIR, felsóköpeny xenolit, geofizika, reológia, Kárpát-Pannon régió, Persány hegység

\section{Bevezetés}

HORVÁTH Ferenc professzor személye nem csupán a geofizikai kutatásokban volt meghatározó, hanem a tudományterületek integrálásában is élen járt. Így vált a KárpátPannon régió (KPR) fejlődéstörténetének egyik emblematikus kutatójává. Eredményei, hipotézisei jelenleg is ösztönzőleg hatnak a KPR témájú kutatásokra. Felismerte, hogy a mélyebb litoszférából származó xenolitokban rejlő ismeretek jelentôs potenciállal bírnak a geodinamikai modellekben. HoRvÁTH professzor mindig nyitott volt a megbeszélésekre és vitákra, és nem sajnálta az idôt arra, hogy megtalálja a közös nyelvet a kôzettan és geokémia szakterület múvelőivel is. Jelen dolgozatunk HoRvátH Ferenc professzor ezen tevékenysége előtt (is) kíván tisztelegni.

A felsőköpenyben és alsókéregben található ásványok döntő többsége (olivin, piroxén, spinell, gránát) ún. névlegesen vízmentes ásvány (angol megfelelője - nominally anhydrous minerals - után: NAMs). Víztartalmú elegyrészek (pl. amfibol, csillám, apatit) kis mennyiségben vannak jelen ilyen körülmények között. Névlegesen vízmentes ásványnak hívjuk mindazon ásványokat, amelyek sztöchiometrikusan nem tartalmaznak, ,vizet" $\left(\mathrm{OH}^{-}\right.$és $\left.\mathrm{H}_{2} \mathrm{O}\right)$, azaz a „víz” kizárólag nyomnyi mennyiségben fordul elô az ásvány szerkezetében, azonban így is jelentős hatással van a kőzetek olvadáspontjára, reológiájára, továbbá a hullámterjedési sebességre és elektromos vezetóképességére (pl. KoHLsTEDT et al. 1996, DiXON et al. 2004, Li et al. 2008, INOUE et al. 1998, Karato et al. 1986, Karato 1990). A H ${ }^{+}$egyrészt beépülhet az adott ásvány rácsszerkezének vakanciáiba, másrészt a koordináló oxigénnel összekapcsolódva szerkezeti hidroxilt alkot (a továbbiakban ezekre szerkezeti hidroxil megjelöléssel hivatkozunk, és amennyiben a hidrogén egyéb előfordulási módjáról van szó, azt külön jelezzük). A nyomelemnyi mennyiségú „víz” mennyiségi és minőségi mérésére a Fourier transzformációs infravörös (FTIR) spektrometria módszere bizonyul a legpraktikusabbnak, kis kimutatási határa ( ppm), pontossága (átlagos hibahatár 15\%), kis mintaelőkészítési igénye és költséghatékonysága miatt (pl. LibowitzKy \& Rossman 1996, LiBOwITZKY 2006, Kovács et al. 2008). Az utóbbi néhány évtized kísérleti munkáinak során több közlemény született a földköpenyben előforduló NAM szerkezeti hidroxil tanulmányozásáról (pl. olivin: MACKweLL \& KOHLSTEDT 1990; Bai \& KoHLSTEDT 1992, 1993; Kovács et al. 2010; BALAN et al. 2011; INGRIN et al. 2014; klinopiroxén: STALDER \& LUdWIG 2007; ortopiroxén: RAUCH \& KePPLER 2002; gránát: ACKermann et al. 1983; Rossman \& AINES 1991; LU \& KEPPLER 1997). A tanulmányok fő eredményei között szerepel a szerkezeti hidroxil szoros kapcsolatának kimutatása a kőzetek olvadáspontjával és tettenérhető metaszomatikus eseményekkel. A névlegesen vízmentes ásványok szerkezeti hidroxil mennyisége alapján többek között a rendszer $\mathrm{SiO}_{2}$ aktivitását és $\mathrm{H}_{2} \mathrm{O}$ tartalmát megváltoztató metaszomatikus folyamat is felismerhető (pl. MATVEEV et al. 2001). GREEN et al. (2010) kimutatta, hogy a litoszferikus földköpenyben igen kis mennyiségú $(0,02$ tömeg\%) szerkezeti hidroxil koncentráció esetén már létrejöhet pargasitos amfibol, ami a földköpeny olvadáspontját jelentős mértékben, mintegy $150-200^{\circ} \mathrm{C}$-kal csökkentheti. Azonban a NAM elegyrészek szerkezeti hidroxil koncentrációja nem csak a litoszferikus köpenyre meghatározó jelentőségú. Jól mutatja ezt PLANK et al. (2013) és BIRó et al. (2016), akik kimutatták, hogy a névlegesen vízmentes magmás fenokristályokban (pl. kvarc, plagioklász, klinopiroxén és olivin) előforduló szerkezeti hidroxil információt adhat a kristállyal egyensúlyban lévő olvadék „víz”-tartalmáról, így hozzájárulhat egy vulkánkitörés jellegének alaposabb megismeréséhez. Ezek alapján jól látható, hogy a „víz” alapvetô szerepet játszik a litoszferikus köpeny és a kéreg geodinamikai alakításában, valamint az ott lejátszódó folyamatok fejlődésében.

A KPR-ben a neogén alkáli bazalt vulkanizmus nagyszámú litoszferikus földköpeny xenolitot szállított a felszínre (pl. VASELli et al. 1995, FALUS et al. 2000, SzABó et al. 2004, HIDAS et al. 2007, BERKESI et al. 2012, BALI et al. 2008, GuZMics et al. 2008, LiPTAI et al. 2017, ARADI et al. 2017; PAтKó et al. 2019). A felsóköpeny xenolitot tartalmazó öt alkáli bazalt vulkáni terület (Stájer-medence, BakonyBalaton-felvidék, Kisalföld, Nógrád-Gömör és Persány hegység) részletes FTIR vizsgálat ezidáig a Nógrád-Gömörből (PATKó et al. 2019) és a Stájer-medencéról (ARADI et al. 2017) származó xenolitokon készült. Ezen tanulmányok 
szerzői kimutatták, hogy a KPR peremén fekvő Stájer-medence földköpeny xenolitjainak NAM elegyrészei szerkezeti hidroxilban gazdagok, míg a Nógrád-Gömöri xenolitok „víz”-ben jelentősen kimerültek. Az említett munkák mellett a Persány hegységből is rendelkezésünkre állnak adatok (FALUS et al. 2008). Utóbbi közlemény két lelőhely vizsgálata alapján keresett összefüggést a gyengén és erôsen deformált xenolitok ásványainak szerkezeti hidroxiltartalma között.

Munkánkban összefoglaljuk a FTIR spektrometria alapjait és alkalmazhatóságát, majd kitekintünk a Persány hegységi vulkáni terület alatti litoszferikus földköpeny víztartalmára. Egy jellegzetes, Grujuról származó xenolit példáján bemutatjuk, hogy a döntő többségben bazaltos kőzetekben előforduló felsőköpeny-fragmentumok szerkezeti hidroxiltartalma hogyan használható fel geofizikai alkalmazásra (elsősorban fajlagos vezetőképesség és viszkozitás meghatározására), és adott esetben a Kárpát-Pannon régióban ez milyen geodinamikai következtetések levonását teszi lehetővé.

\section{A Persány hegységi vulkáni terület földtani hátterének rövid ismertetése}

A Persány hegységi vulkáni terület (PHVT) a KPR neogén monogenetikus vulkáni mezők legfiatalabbika. A rövid ideig tartó (1,2-0,6 Ma; PANAIOTU et al. 2013, SEGHEDI et al. 2016) alkáli bazaltos vulkanizmusról és a felszínre hozott szubkontinentális litoszféra eredetû xenolitokról már több publikáció született (pl. DownEs et al. 1995; VASELLI et al. 1995; ChALOT-PrAT et al. 1998; FAlus et al. 2000, 2008, 2011; Tóth et al. 2006; HARANGI et al. 2013; LUFFI et al. 2015; KovÁcs et al. 2018; SÁGI et al. 2018). A területtől keletre található a Vráncsa-zóna, amely ismert a nagy magnitúdójú (Richter skálán 6 feletti) közepes és nagy mélységben (70-170 km) kipattanó földrengéseiről (VACAREANU \& IONESCU 2016). E földrengések hipocentrumai átfednek a szeizmikus tomográfia segítségével kitérképezett, nagy szeizmikus sebességgel jellemzett kôzettérfogattal, amit az irodalom alábukó (szubdukálódó/delamináló) lemez maradványaként értelmez (WORTEL \& SPAKMAN 2000, TONDI et al. 2009, BARON \& Morelli 2017). A lemez geometriája alapján a Persány hegység alatt található földköpeny egy köpenyéknek fogható fel. FALus et al. (2000) és TóTH et al. (2006) igazolta, hogy a Persány hegység alatt a földköpeny felemelkedett, ami az alkáli bazaltos vulkanizmus keletkezéséhez vezethetett (HARANGI et al. 2013). A PHVT alkáli bazalt által felhozott földköpeny xenolitok petrográfiai tulajdonságai változatosak. A területre jellemző erôsen deformált (milonitosodott) peridotitokkal (FALUS et al. 2008; 2011) és a gránáttartalmú piroxenitekkel TóTH et al. (2006) és LuFFI et al. (2015) foglalkozott érdemben. A xenolitokban gyakran megjelenő amfibol és annak geokémiai tulajdonsága alapján (VASELli et al. 1995, CHALOT-PrAT et al. 1998, SzABó et al. 2017) a Persány hegység alatt található földköpeny jelentős metaszomatózison esett át, ami feltételezhetően a Vráncsa-zónában található alábukó lemezből felszabaduló fluidumokhoz köthetô.

\section{Módszertan}

\section{A Fourier-transzformációs infravörös spektroszkópia alapjai}

Az infravörös spektrometria alapja, hogy az ásványokban fellépő kémiai kötések rezgései milyen hullámszámnál (energiánál) nyelik el az infravörös fényt, illetve mekkora az elnyelődés mértéke. Az elnyelődés hullámhossza alapján az elnyelő komponens leggyakrabban azonosítható, annak mértéke alapján pedig az abszolút koncentrációja is meghatározható mólban vagy még gyakrabban tömeg\%-ban kifejezve. Az FTIR mérés során az elektromágneses hullámspektrum infravörös tartományát (780 nm - $1 \mathrm{~mm}$ ) használjuk, és a mintán áthaladó sugárzás elnyelődését vizsgáljuk hullámszám szerint a háttér intenzitására vonatkoztatva (LIBOWITZKY \& RoSSMAN 1996). A spektrumon található elnyelődési sáv helye a szerkezeti hidroxil beépülésének módjától, az elnyelődés intenzitása pedig annak mennyiségétôl függ (LIBOWITZKY 2006)

A mikro-FTIR spektrometriához alkalmazott múszer a spektrométerből (amelynek legfontosabb részei a „Glowbar” forrás, az interferométer, optikai rendszer) és a hozzá tartozó infravörös mikroszkópból épül fel. Az infravörös sugárzás létrehozásához leggyakrabban SIC „Glowbar” (,izzó rúd”) sugárforrást izzítunk kb. 800 C-ra. A kibocsátott infravörös sugárzást az interferométer segítségével moduláljuk és lencserendszerek segítségével vezetjük át a mikroszkóp tárgyasztalán, majd juttatjuk a detektorba. A kapott interferogramokat a Fourier-transzformáció matematikai múveletével alakítjuk át olvasható spektrumokká. A detektor leggyakrabban HgTe és CdTe (Mercury-CadmiumTelluride = MCT) ötvözetből készül, ami folyékony nitrogénnel hútve az infravörös sugárzás nagy érzékenységú detektálását teszi lehetővé.

A ,Glowbar” forrásból kibocsátott infravörös fény alapvetôen nem poláros jellegú, ami polarizátorokkal polarizált fénnyé alakítható. Természetesen a primer, nem poláros fény is részben polarizált, ugyanis az optikai rendszeren történő reflexiók során részben polárossá válik. Az infravörös sugárzás egymásba forduló kúppalástok mentén terjedve halad át a mintán az objektíveknek köszönhetően, amelyeknek fókuszában ideálisan a minta van. Az ilyen módú fényterjedés a felhasználás szempontjából lényeges, ugyanis alaphelyzetben a spektrométerben az infravörös sugárzás párhuzamos sugárnyalábok formájában halad át a mintán. A kúppalást menti terjedésnek köszönhetően az ideális vastagságú mintáknál vastagabb (> 200 m) minták esetében előfordulhat, hogy nemcsak a fókuszban lévő területét, hanem annak szúkebb környezetét is vizsgáljuk (1. ábra).

A mintára érkező infravörös sugárzás egy része elnyelődik, egy része pedig áthalad azon. Az elnyelt sugárzás hullámhosszértéke adja a minőségi, az elnyelődés mértéke pedig a mennyiségi információt a kölcsönhatásra vonatkozóan. A mérések során azt határozzuk meg, hogy egy adott hullámszámnál mért intenzitás $\left(\mathrm{I}_{0}\right)$, hogyan viszonyul a mintán mért intenzitáshoz (I). E két intenzitás hányadosát 


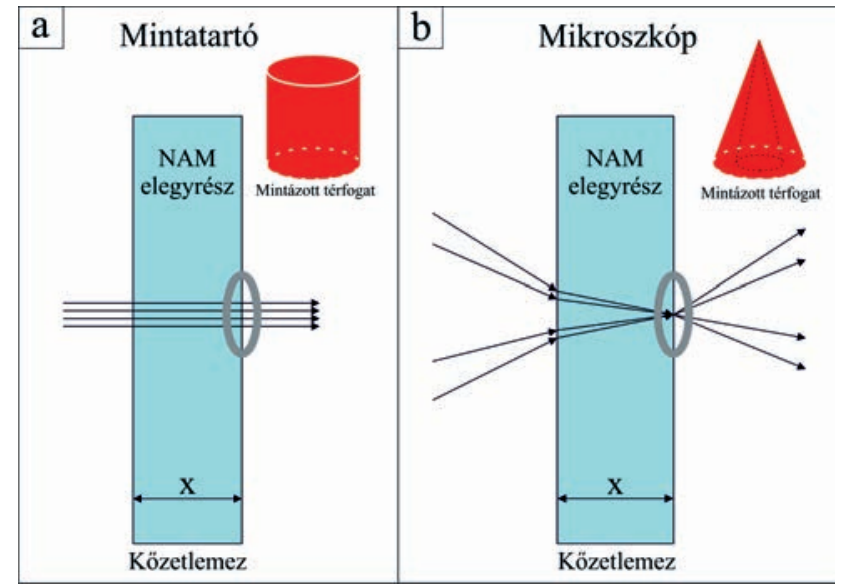

1. ábra. A mintatartón található $X$ vastagságú vékonycsiszolaton áthalado infravörös fény (a) henger és (b) kúp alakú útvonala. A kúp alakú útvonal során a fény kisebb térfogatot mintáz meg

Figure 1. Infrared light travels through thin section of the samples that has a thickness of $X$ in the form of (a) cylinder and (b) cone. Notice that the light that travels in the form of cone sample has smaller volume than the light that travels in the form of cylinder

nevezzük transzmittanciának (átlátszóság) $\left(\mathrm{T}=\mathrm{I} / \mathrm{I}_{0}\right)$, aminek értéke 1 , amennyiben nincsen elnyelődés, és 0 , amennyiben minden sugárzás elnyelődik. A transzmittancia azonban gyakorlati szempontból nehezen használható, hiszen értéke az elemzett minta vastagságával exponenciálisan változik. Ezért a gyakorlatban inkább az abszorbancia értékének az alkalmazása terjedt el. Az abszorbancia a transzmittancia negatív 10-es alapú logaritmusa $\left(\mathrm{A}=-\log (\mathrm{T}) ; \mathrm{A}=-\log \left(\mathrm{I} / \mathrm{I}_{0}\right)\right.$ vagy $\left.\mathrm{T}=10^{-\mathrm{A}}\right)$. Az abszorbancia 0 , ha nincsen semmilyen elnyelődés,és végtelen, amennyiben minden sugárzás elnyelődik. Értéke lineárisan változik a minta vastagságával.

A NAM elegyrészek vizsgálatához rendszerint 200-300 $\mu \mathrm{m}$ vastag, duplán polírozott vékonycsiszolat szükséges, amelyet a preparálás után leoldunk a tárgylemezrôl, és ezt a tiszta mintalemezt helyezzük a tárgyasztalra. Amennyiben a vizsgált mintában lévő NAM elegyrészek víztartalma nagy (pl. olivin: >10 ppm; ortopiroxén: >100 ppm; klinopiroxén: $>500$ ppm), a vastagság lehet kisebb is (néhány $10 \mu \mathrm{m}$ ), azonban sokkal nagyobb vastagság alkalmazása az infravörös sugárzás már említett kúppalást menti terjedéséből következően nem célszerú.

A rutin mérések során a vizsgált területet apertúra segítségével határoljuk le, amelynek mérete alapesetben 100* $100 \mu \mathrm{m}$ (rendszerint négyzet vagy téglalap alakú), ami csökkenthetô. Az eddigi tapasztalatok alapján a „Glowbar” sugárforrással elvégezhetô elégséges minőségú mérések a NAM elegyrészek esetében $30 * 30 \mu$ m apertúra mellett még kivitelezhetôk. Nagyobb felbontás eléréséhez szinkrotron sugárforrás használatára lehet szükség, aminek jelerôssége rendszerint egy nagyságrenddel meghaladja a hagyományos „Glowbar” forrásét. A felbontás szinkrotron esetében akár néhány mikrométer is lehet, azonban a gyakorlat azt mutatja, hogy az 5-7 $\mu \mathrm{m}$ körüli a legjobb érték. A valós laterális felbontást nagyban korlátozza, hogy az infravörös sugárzás kúppalást mentén terjed, és a csiszolatok rendszerint lénye- gesen vastagabbak ettől az értéktől. Ennek köszönhetően valószínú, hogy nemcsak az apertúra által lefedett és a fókuszban lévő területrôl, hanem kívülrôl is érkezhet spektrális jel. Így lehetôleg nagy méretű (>500 nm), homogén egykristályokat és azoknak is inkább a központi részét célszerú vizsgálni. A mérések eredményei spektrumok, amelyeken rendszerint az abszorbanciát ábrázoljuk a hullámszám függvényében. A hullámszám a hullámhossz inverze, amely az infravörös mérések során jellemzően néhány száz vagy néhány ezer reciprok centimétert $\left(\mathrm{cm}^{-1}\right)$ jelent.

A mérések során számos mérési paraméter beállítására nyílik lehetôség. Gyakorlati szempontból ezek közül a legfontosabbak a spektrális tartomány, a spektrális felbontás és a leolvasások száma. A NAM elegyrészek esetében a 400 $-4000 \mathrm{~cm}^{-1}$ közötti spektrális tartomány a legérdekesebb, ugyanis itt fordulnak elő a karakterisztikus O-H rezgések és a szilikátvázra jellemző Si-O rezgések, valamint ezek felharmonikusai. Hullámhosszban kifejezve ez a 2,5-25 $\mu \mathrm{m}$ tartománynak felel meg. A kőzetüvegben lévő „víztartalom" vizsgálatához szükséges lehet a tartományt egészen $6000 \mathrm{~cm}^{-1}$-ig kibóvíteni, hiszen így az $\mathrm{OH}^{-}$és $\mathrm{H}_{2} \mathrm{O}$ formájában megkötött „,víz” is mennyiségileg elkülöníthetô sorrendben a 4500 és $5200 \mathrm{~cm}^{-1}$-nél tapasztalható elnyelési sávjaik alapján (MANDEVILLE et al. 2002).

A spektrális felbontás megadja, hogy a vizsgált spektrális tartomány milyen súrún mintavételezett, azaz hány hullámszámonként mérjük az abszorbancia értékét. Minél kisebb a vizsgálandó elnyelési sávok félértékszélessége, annál sûrúbben szükséges mintavételezni, hogy a spektrális felbontást növeljük. A szerves anyagok és a nagy rendezettségú anyagok esetében nem ritka a néhány hullámszámnyi félértékszélesség sem, ami azt jelenti, hogy a felbontásnak is $<1 \mathrm{~cm}^{-1}$-nek kell lennie. A mérések ideje a spektrális felbontás növelésével növekszik, így szükséges vizsgálni, hogy melyik az a spektrális felbontás, ami mellett minden releváns abszorbanciasáv detektálható és a mérési idő sem irreálisan hosszú (pl. több mint fél óra). Ennek meghatározása céljából a pakisztáni sztenderd olivin kristály (KovÁcs et al. 2008) szisztematikus mérését végeztük el különböző spektrális felbontással. Az eredmények arra utalnak, hogy 4 $\mathrm{cm}^{-1}$-nél nagyobb felbontás esetében már nem nyerhető többletinformáció, azaz a legfontosabb elnyelési sávok mind jól elkülöníthetők. Mivel a többi szilikát NAM elegyrész - főleg piroxének, gránát és földpát — sávjainak félértékszélessége még az olivin sávjainál is nagyobb, ezért a $4 \mathrm{~cm}^{-1}$-es felbontás a rutin mérések elvégzésére alkalmas.

A mérések során szintén beállítható, hogy a megjelölt spektrális tartományt hányszor mérje le a berendezés, amit a leolvasások (scan) számaként adhatunk meg. A leolvasások számának növelése javítja a jel/zaj arányt, ami az alkalmazott leolvasások négyzetgyökével arányosan javul, azonban túl sok leolvasás jelentősen megnövelheti a mérési időt, ami a mérési körülmények változása miatt (atmoszferikus interferencia) végeredményben a mérési eredmények minőségét akár kedvezôtlenül is befolyásolhatja (LiBOwITZKY 2006) (2. ábra). A 2. ábra alapján az is látszik, hogy kb. 128 leolvasás után már nem következik be további jelentôs 


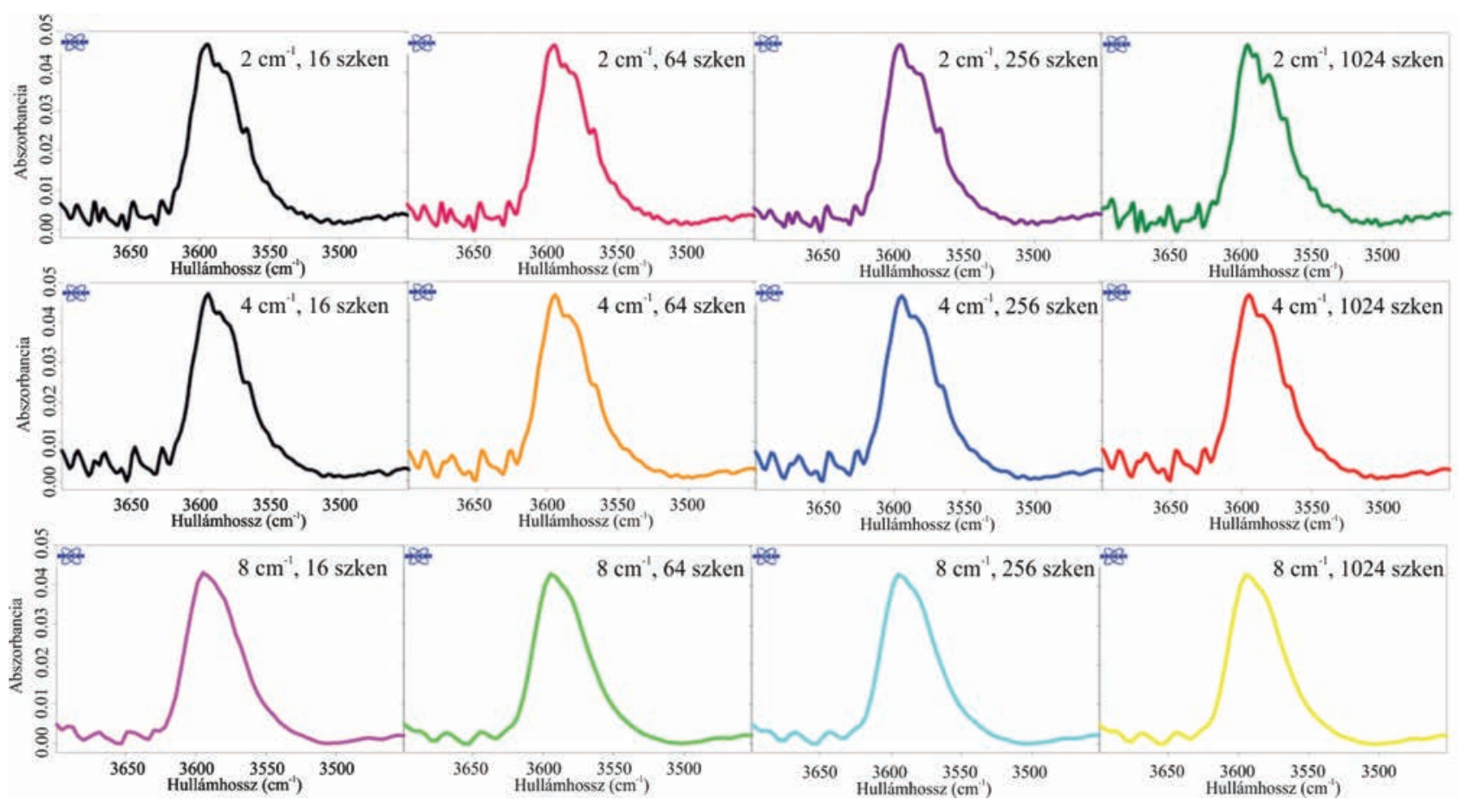

2. ábra. A pakisztáni olivinen végzett FTIR vizsgálat során kapott spektrumok minősége az OH-tartományra vetítve. Az ábrázolt spektrumok felbontása 2 , 4 és 8 $\mathrm{cm}^{-1}$, ezekhez társított szken számok 16, 64, 256 és 1024. Megfigyelhető, hogy a spektrumok zavarossága a felbontás és a szkenek számával csökken. Azonban túl nagy felbontás és szken szám túlsimítást okoz, ami információ vesztéshez vezethet

Figure 2. Spectra of FTIR measurements for OH-interval in the Pakistan olivine. Resolution of the spectra is 2, 4 and $8 \mathrm{~cm}^{-1}$, the used scan number is $16,64,256$ and 1024. Smoothing of the spectra increases by increasing the resolution and number of scans. Notice that too high resolution and scan number can lead loss of information because of the over smoothed surface

minőség javulás. İgy a NAM elegyrészek méréséhez rutin esetekben 128 leolvasás javasolt. A leolvasások száma nem feltétlen szükséges, hogy a kettő hatványa legyen, de a leolvasások száma és a jel/zaj arány közötti négyzetgyökös összefüggés miatt praktikus.

\section{Mérés során felléphetố problémák és azok kiküszöbölése}

A mikro-FTIR spektrometria kis kimutatási határa $(\sim 1$ ppm tömegrész ,víz” egyenértékben) miatt számos tényező befolyásolhatja a mérések kimenetelét és az adatok minőségét. Különösen igaz ez a $\mathrm{CO}_{2}$ és az $\mathrm{OH}^{-}, \mathrm{H}_{2} \mathrm{O}$ kimutatása esetében, ahol az atmoszferikus hatások jelentősen növelhetik a kimutatási határt és a kapott abszolút koncentráció bizonytalanságát.

A mintaelőkészítés során törekednünk kell arra, hogy a minta felületéről minden szerves anyagot és ,,vizet” eltávolítsunk. Szerves anyag (pl. vékonycsiszolatok készítésekor használt ragasztó) maradványainak eltüntetésének céljából a mintát legalább 24 órán át acetonban célszerú áztatni. Ezt követően a mintát kemencébe helyezzük és ott 1-2 órán keresztül legalább $80^{\circ} \mathrm{C}$ hômérsékleten állni hagyjuk (egyes amorf szerkezetú ásványok stabilitása még $80^{\circ} \mathrm{C}$ alatt megszúnik, így ezek vizsgálatakor szárításhoz kisebb hőmérsékletet használunk). Előbbi eljárással — a mintán található - felületi víz jelentős része eltávolítható. Végezetül a teljesen kiszáradt mintát jól zárható, száraz mintatartóba tesszük, és kizárólag a mérés előtti pillanatokban vesszük ki. Fontos, hogy ujjunkkal ne érjünk a mintához, mert a bőrön található nedvesség és szerves anyag jele visszaköszönhet a spektrumon.

A mérést (amennyiben lehetséges) jól légkondicionált szobában végezzük, ahol a hőmérséklet és a légnedvesség közel állandó. Fontos a mérés során feljegyezni, hogy éppen milyen a kinti időjárás, ugyanis egy párás nap alkalmával a háttérben a vízgőz jelenléte még akkor is nagy lehet, ha a labor megfelelően légkondicionált. Szintén figyelembe kell venni, hogy az életmúködéshez szükséges biológiai folyamatok révén további vízgőz és $\mathrm{CO}_{2}$ kerül a légtérbe, ami megváltoztathatja a szoba levegôjének pára- és $\mathrm{CO}_{2}$-tartalmát (ez különösen igaz, ha több fő tartózkodik a laboratóriumban). Az atmoszferikus interferencia a spektrumok minőségét jelentősen ronthatja, különösen a vízgőz 3800-3500 $\mathrm{cm}^{-1}$ hullámszámtartományban megjelenő fésûs finomfelhasadásai révén. A múszer nagy érzékenysége miatt a $\mathrm{CO}_{2}$ jellegzetes sávjai $2350 \mathrm{~cm}^{-1}$-nél szinte mindig látszanak. A legtöbb spektrum feldolgozó szoftver (pl. Opus, Omnic, Resolution Pro) ezt a zavaró hatást kezelni tudja a beépített atmoszferikus kompenzáció funkciónak köszönhetően. Ezenkívül hatékony megoldás a mintaasztalt és a mikroszkóp objektívjeit egy kamra segítségével elzárni és abban inert gázt $\left(\mathrm{N}_{2}\right.$, He vagy Ar) áramoltatni. Az atmoszféra és a mérési körülmények stabilitása ellenőrizhető, ha a háttér 
mérését követően a hátteret „mintaként” is megmérjük. Amennyiben nincs semmiféle múszeres és atmoszferikus „drift”, akkor a mintaként felvett háttér spektrum egy 0 abszorbanciánál futó vízszintes egyenes.

\section{A $\mathrm{H}^{+}$beépülésének módjai névlegesen vízmentes ásványok szerkezetébe}

A spektrális ,víz” tartományon belül lehetőségünk van elkülöníteni (1) molekuláris $\mathrm{H}_{2} \mathrm{O}-\mathrm{t}\left(\sim 3400 \mathrm{~cm}^{-1}\right.$-nél megjelenő nagy félértékszélességú széles sáv), (2) szerkezeti hidroxilt, ahol a $\mathrm{H}^{+}$vakanciákba épül be önállóan vagy más kationnal csatolt helyettesítést létrehozva (mindkét esetben kis félértékszélességû sávokként 3650 és 3000 cm-1 között) és (3) szerkezeti hidroxilt, ami olyan ásványt képvisel, amiben a $\mathrm{H}^{+}$sztöchiometrikusan előfordul (rendszerint 3650 $\mathrm{cm}^{-1}$-nél nagyobb hullámszámnál).

Az olivin a képlete alapján $\left((\mathrm{Mg}, \mathrm{Fe})_{2}\left[\mathrm{SiO}_{4}\right]\right)$ nem tartalmaz molekuláris vizet, sem sztöchiometrikus szerkezeti hidroxilt. Azonban előfordulhat benne fluidumzárvány és/vagy vakanciát betöltő szerkezeti hidroxil. A csapdázódott fluidum- vagy olvadékzárványok molekuláris vizet tartalmazhatnak (HIDAS et al. 2010). A geofizikai számí- tások jelenleg nem veszik figyelembe a fluidumzárványok jelenlétét, azonban elképzelhetô, hogy a jövőben a pontosítás érdekében nagy szerepet fognak játszani. Kísérleti munkák kimutatták, hogy a $\mathrm{H}^{+}$többféleképpen képes beépülni (pl. MATVEeV et al. 2001; BERRY et al. 2005, 2007; KovÁcs et al. 2010; BALAN et al. 2011). Az egyik lehetőség négy $\mathrm{H}^{+}$beépülése a $\mathrm{Si}^{4+}$ rácspozíciójába (üres szilikát tetraéderbe/tetraéderes vakanciába) (3. ábra), amit „,hidrogránát” $\left(\mathrm{Mg}_{2} \mathrm{H}_{4} \mathrm{O}_{4}\right)$ helyettesítésnek is neveznek (pl. KovÁcs et al. 2010). Az üres szilikát tetraéderek előfordulása a rendszer kis $\mathrm{SiO}_{2}$ aktivitásával magyarázható (LEMAIRE et al. 2004). Ebben az esetben kizárólag $\mathrm{H}^{+}$helyettesítésről beszélhetünk, amelynek sávpozíciói 3612, 3580, $3566 \mathrm{~cm}^{-1}$-nél található (3. ábra). A másik lehetőség, hogy a $\mathrm{H}^{+}$helyettesítés az oktaéderes (M1 vagy M2) pozíciókban történik (KovÁcs et al. 2010). Ez esetben a két $\mathrm{H}^{+}$helyettesít egy bivalens kationt $\left(\mathrm{MgH}_{2} \mathrm{SiO}_{4}\right.$, jellemzően $\mathrm{Mg}^{2+}$ vagy $\left.\mathrm{Fe}^{2+}\right)$. Ennek a helyettesítésnek a sávjai 3220 és $3160 \mathrm{~cm}^{-1}$-nél helyezkednek el (KovÁcs et al. 2010; BALAN et al. 2011).

Előfordulhat továbbá, hogy a $\mathrm{H}^{+}$valamilyen egyéb kationnal együtt épül be különböző kristálytani pozícióba és vakanciába, amit csatolt helyettesítésnek hívunk (pl. BERRY et al. 2005). Ebben az esetben a szilikát tetraéderbe egy
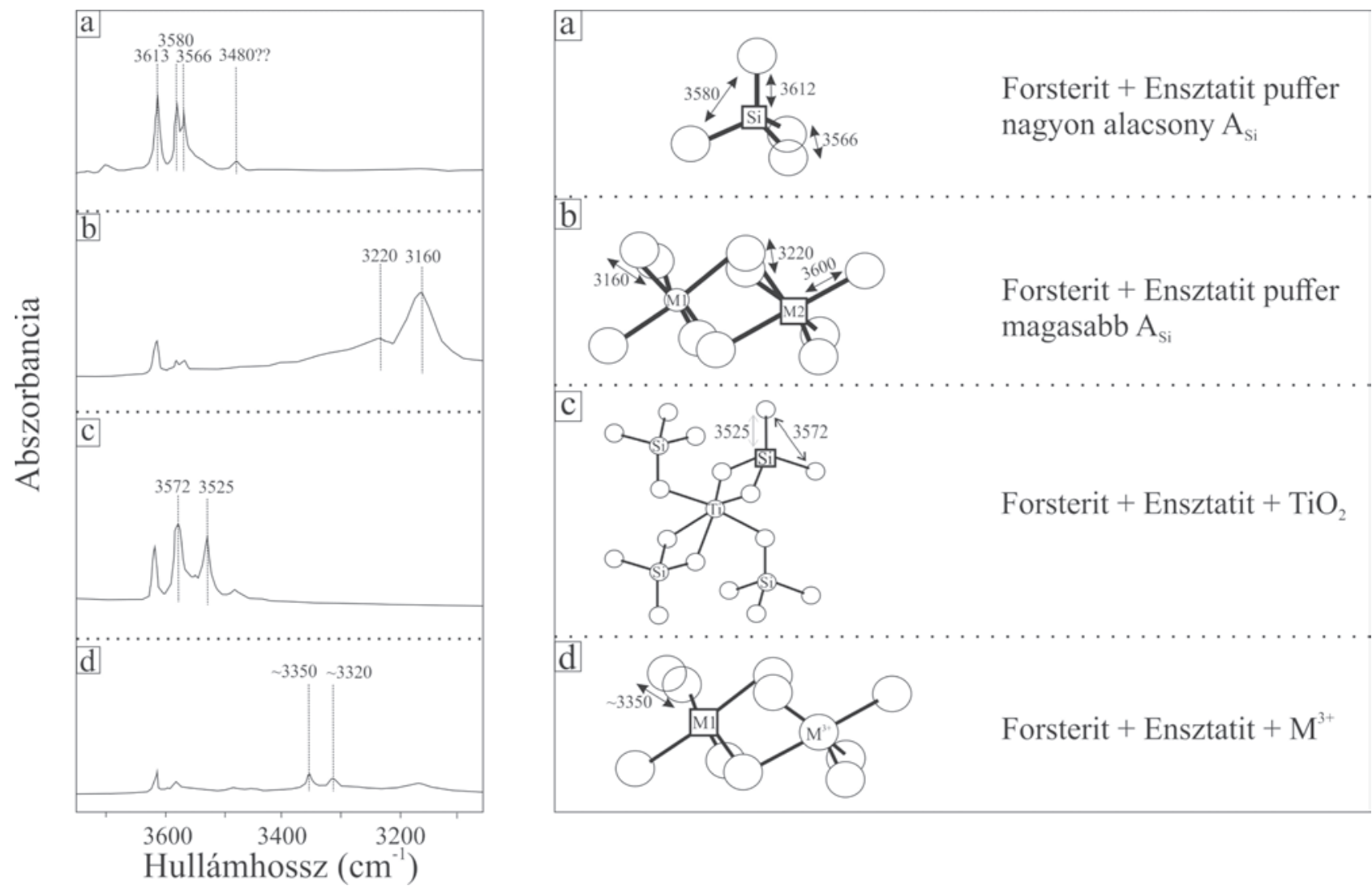

c

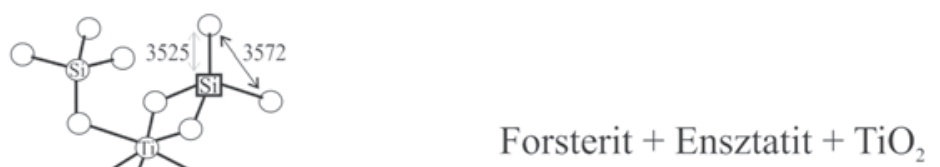

3. ábra. Olivin szerkezetébe történő $\mathrm{H}^{+}$beépülés különböző lehetőségei és a hozzátartozó abszorbancia pozíciói (KovÁcs et al. 2010 alapján). a) Kis Si aktivitás mellett történő $\mathrm{H}^{+}$beépülés az $\left[\mathrm{SiO}_{4}\right.$ ] tetraéderbe. b) Nagy Si aktivitás mellett történő $\mathrm{H}^{+}$beépülés az $\mathrm{M} 1$ és $\mathrm{M} 2$ oktaéderes pozícióba. c) $\mathrm{Nagy}_{\mathrm{TiO}}$ aktivitás mellett történő $\mathrm{H}^{+}$beépülés (=klinohumit szerkezet kialakulása olivinben). d) Három vegyértékủ kation és $\mathrm{H}^{+}$együttes beépülése

Figue 3. Different types of $\mathrm{H}^{+}$incorporation into olivine and their related absorbance peak. a) $\mathrm{H}^{+}$incorporation in low Si activity environment. b) $\mathrm{H}^{+}$incorporation in high Si activity environment. c) $H^{+}$incorporation with Ti in high TiO, activity environment resulting in clinohumite structure within olivine. d) Trivalent cation and $H^{+}$joint incorporation into olivine structure 
trivalens kation $\left(\mathrm{pl} . \mathrm{Al}^{3+}, \mathrm{Ti}^{3+}\right.$ ) és egy $\mathrm{H}^{+}$épül be egyszerre (pl. BERRY et al. 2007). A titán-klinohumit ponthiba esetében egy $\mathrm{Ti}^{4+}$ lép be egy oktaéderes vakanciába, a közvetlenül mellette lévő tetraéderes vakanciába pedig két $\mathrm{H}^{+}$ $\left(\mathrm{MgTiH}_{2} \mathrm{O} 4\right)$. E csatolt beépülés elnyelési sávjai 3572 és $3525 \mathrm{~cm}^{-1}$-nél jelennek meg. A felsőköpeny xenolitok olivinjében ez az egyik leggyakrabban előforduló helyettesítési mechanizmus (PADRON-NAVARTA \& HERMANn 2017). BERRY et al. (2007) számos trivalens kation és $\mathrm{H}^{+}$csatolt helyettesítését (pl. $\mathrm{B}^{3+}, \mathrm{Al}^{3+}, \mathrm{Sc}^{3+}, \mathrm{Ti}^{3+}, \mathrm{V}^{3+}, \mathrm{Cr}^{3+}, \mathrm{Fe}^{3+}, \mathrm{Lu}^{3+}$ ) vizsgálták. Megfigyeléseik alapján az ilyen típusú helyettesítések elnyelési sávjai általában 3400 és $3300 \mathrm{~cm}^{-1}$ között helyezkednek el. Az adott típusú helyettesítés helye ezen a tartományon belül függ az adott kation tulajdonságaitól (elsôsorban az ionrádiuszától).

A tapasztalatok szerint a klinopiroxénekben előforduló amfibol lamellák — amelyek esetenként polarizációs mikroszkópban sem láthatók — a 3675-3695 cm ${ }^{1}$ tartományban észlelhetô elnyelési sávokkal azonosíthatók (pl. DeLLA VENTURA et al. 2007). Hasonló szubmikronos átalakulás az olivin szerpentinné vagy talkká történő átalakulása, amit a $3700 \mathrm{~cm}^{-1}$ körüli elnyelési sávok (szerpentinre), illetve a 3709,3685 és $3645 \mathrm{~cm}^{-1}$-nél található sávok (talkra) jelzik (Miller et al. 1987).

\section{„Vizz" koncentráció meghatározása}

Az infravörös spektrometria földtudományi alkalmazásai során anizotróp ásványokat mérünk, ahol az abszorbancia sávok helye és intenzitása függ az ásvány orientációjától, ami megnehezíti a precíz mennyiségi kiértékelést, különösen finomszemcsés minták esetében $(<0,7 \mathrm{~mm})$.

A koncentráció számolása a Beer-Lambert törvény alkalmazásával történik:

$$
\mathrm{c}=\frac{A^{t o t} * M_{A}}{\varepsilon * t * \rho} * 100
$$

ami kimondja, hogy egy adott elem koncentrációja (c [ppm tömegrész]) egyenesen arányos az elemre vonatkozó teljes abszorbanciával $\left(\mathrm{A}^{\mathrm{tot}}\right)$, a moláris tömeggel $\left(\mathrm{M}_{\mathrm{A}}[\mathrm{g} / \mathrm{mol}]\right)$ és fordítottan arányos a moláris integrált kioltási együtthatóval $\left(\varepsilon\left[\mathrm{L} / \mathrm{mol} \times \mathrm{cm}^{2}\right]\right)$, a sưrúséggel $(\rho[\mathrm{g} / \mathrm{L}])$ és a vastagsággal $(\mathrm{t}[\mathrm{cm}])$. Az abszorbancia értéke mérhető az adott elnyelési sáv intenzitásaként az alavonalhoz viszonyítva. Az abszorbancia azonban kifejezhetô az elnyelési sáv integrált területeként is. LiBowitzKy \& Rossman (1997) megállapította, hogy földtani mintákban az integrált terület meghatározása rendszerint kisebb hibával terhelt, ezért célszerú azt használni az abszorbancia értékének meghatározásához. Jelen tanulmányunkban az abszorbancia mérôszámaként integrált abszorbanciát értünk.

Az adott elem által létrehozott kötésekre történố teljes integrált abszorbanciát a következő módon tudjuk meghatározni. Először alapvonalkorrekciót alkalmazunk, majd az adott kötéstípusok sávtartományát kijelöljük és integráljuk a görbe alatti területet kiértékelő szoftver segítségével, ami esetünkben a Bruker Opus programcsomagja volt. Bár az alapvonalkorrekció elvégezhetô manuálisan is, az összehasonlíthatóság érdekében érdemes a szoftverben található ún. konkáv gumikötél (concave rubber band) korrekciót használni 64 illesztôponttal és 1-4 iterációval. Ez a háttérkorrekciós módszer jól múködik a legtöbb NAM elegyrész esetében. Nagyobb mértékú túlkompenzációt a háttérkorrekciós módszer csak nagy félértékszélességú elnyelési sávok esetében okozhat, mint például fluidumzárványok molekuláris vízcsúcsa, vagy a plagioklászban kötött szerkezeti hidroxil spektruma. Fontos, hogy egy adott mintasorozat ásványai esetében mindig ugyanazokat a tartományokat jelöljük ki és integráljuk.

\section{Poláros és nem poláros módszer rövid ismertetése és összehasonlítása}

A földtudományban sokáig tartotta magát az a nézet, hogy mennyiségi infravörös spektrometriához csak a poláros infravörös fény alkalmazható (BELL et al. 1995, 2003, 2004; LiBOwITZKy \& Rossman 1996). E módszer esetén a vizsgált ásványt az összes fő kristálytani tengelye mentén orientált poláros fénnyel kell lemérni, hogy megkapjuk a három fố abszorbanciaértéket $\left(\mathrm{A}_{\mathrm{tot}}=\mathrm{A}_{\mathrm{a}}+\mathrm{A}_{\mathrm{b}}+\mathrm{A}_{\mathrm{c}}\right)$. A mérések elvégezhetốk úgy is, hogy három tetszőleges, de egymásra meróleges metszet fő elnyelési értékeit állapítjuk meg, majd ezek átlagának összegét vesszük. A poláros fénnyel történő mérés során a mintaelókészítés idôigényes, és a legjobb igyekezet ellenére sem garantált, hogy a különböző metszetek tökéletesen 90 fokot zárnak be, és hogy a hasáb oldalai egy irányban lesznek a kristálytani tengelyekkel. A mintaelőkészítés szinte lehetetlenné válik, amennyiben finomszemcsés anyaggal $(<0,7 \mathrm{~mm})$ dolgozunk vagy korlátozott mennyiségú mintával rendelkezünk.

A nem poláros sugárzást sokáig nem használták menynyiségi meghatározásra, mert a nem poláros abszorbancia nem mutatott szisztematikus összefüggést a poláros abszorbanciaértékekkel. Emellett nem találtak lineáris összefüggést az abszorbancia értéke és a mintavastagság között. Később SAMBridge et al. (2008) és Kovícs et al. (2008) kidolgozta az abszorbancia indikatrix teóriát. Ennek értelmében amennyiben a maximális poláros lineáris abszorbancia nem haladja meg a 0,3-at, akkor a poláros és nem poláros abszorbancia között szisztematikus összefüggés áll fenn, és a nem poláros abszorbancia minden esetben a vastagsággal arányosan változik.

A kifejlesztett nem poláros infravörös spektroszkópiai módszer alapján, amennyiben kellő számú orientálatlan ásványt vizsgálunk a mintában és a mérendő $\mathrm{H}^{+}$komponens koncentrációja homogén, akkor a teljes poláros abszorbancia az átlagos nem poláros abszorbanciából is becsülhető. A tapasztalat alapján még erősen anizotróp ásványok (pl. olivin, plagioklász) esetén is elegendó 10 orientálatlan metszeten elvégezni a mérést, meghatározni az egyedi integrált abszorbanciákat, majd ezeket átlagolni és hárommal beszorozni $\left(\mathrm{A}_{\mathrm{tot}}=3 \times \mathrm{A}_{\text {avg }}\right)$. A nem poláros infravörös fényt alkalmazó módszer nem igényel jelentős mintaelőkészítést, ellenben lehetôséget biztosít a kis méretú szemcsék (akár 
néhány $10 \mu \mathrm{m})$ mérésére. Szintén előnyt jelent, hogy rövid idő alatt sok adat nyerhetô. Megjegyezendő továbbá, hogy a nem poláros sugárzás lényegesen erősebb jelet ad a poláros sugárzáshoz képest, továbbá kizárható a poláros módszer pontatlan orientációjából fakadó hiba.

\section{Különbözó integrált moláris kioltási együtthatók}

A teljes poláros abszorbancia ismeretében az abszolút koncentráció meghatározásához megfelelő integrált moláris kioltási együtthatókra van szükség. A gyakorlatban leginkább ásvány specifikus kioltási együtthatókat (I. táblázat; pl. BeLl et al. 1995, 2003; MALDENER et al. 2001; JOHNSON \& Rossman 2003; THOMAs et al. 2009) szoktak használni, amelyek csak az adott sztenderd ásványban tapasztalható infravörös elnyelési sávokra alkalmazhatók. Ez azt jelenti, hogy amennyiben a vizsgált NAM elegyrészek infravörös spektruma jelentősen eltér a sztenderd ásványétól, az együttható alkalmazása jelentôs bizonytalansággal lehet terhelt. Ilyen kis (néhány ppm) koncentrációban a szerkezeti hidroxil tartalom mérése más technikával (például ionmikroszonda) rendkívül nehézkes, és kevés kellően homogén sztenderd ásvány ismert. Ezért a szakterület a rendelkezésre álló néhány nemzetközi sztenderdből (<10 a felsôköpenyre és alsókéregre) indul ki, még akkor is, ha a mért NAM elegyrész infravörös spektruma attól jelentősen eltér.

A kioltási együttható értékének meghatározására részben az előbb ismertetettek miatt is — PATERSON (1982) kidolgozott egy univerzálisnak szánt megoldást, amit LIBOWITZKY \& RossmAN (1997) aktualizált. Eszerint a víztartalmú ásványok elnyelési sávjai és víztartalmuk alap- ján kimutatták, hogy a moláris kioltási együttható értéke a jellemző elnyelési sávok hullámszáma szerint leírható lineáris összefüggést mutat. Ezt nevezték el hullámszámfüggő kioltási együtthatónak. E megközelítés nagy előnye, hogy az bármilyen hullámszámnál megjelenő elnyelési sávokhoz a ,víz” régióban kioltási együtthatót lehet rendelni. A módszer azonban jelentős kihívásokat is rejt. A legjelentősebb ezek közül, hogy az összefüggéseket víztartalmú ásványokon dolgozták ki, ahol a hidroxil nagy mennyiségben, sztöchiometrikusan és nem kis mennyiségben, izolált ponthibákban van jelen. Azonban az izolált ponthibák esetében nem ugyanazok a rezgési energiák lépnek fel a kristályrácsban, mint amikor a hidroxil nagy mennyiségben sztöchiometrikusan épül be. Egy másik alapvető kérdés, hogy hogyan vegyük figyelembe az egymás közelében megjelenô és jelentősen átfedő elnyelési sávokat. Az említett kihívások ellenére ez a megközelítés a mai napig is széles körben használt a NAM elegyrészek abszolút víztartalmának meghatározására.

A legújabb megközelítés az ún. helyettesítés-specifikus kioltási együttható meghatározása, amely különböző kioltási együtthatót rendel a szerkezeti hidrogén különböző beépülési módjaihoz (I. táblázat; KovÁCs et al. 2010). Mivel a különféle sávok és a hozzájuk csatlakozó helyettesítések leginkább az olivinben ismertek (pl. MATVEEV et al. 2001, BALAN et al. 2010), így a helyettesítés-specifikus kioltási együtthatókat is olivinre meghatározva vezették be. Elméleti megfontolások alapján ez lehet a legpontosabb megközelítés, azonban fontos a különböző helyettesítésekhez tartozó elnyelési sávok azonosítása, továbbá ezek integrált területének meghatározása más sávokkal való átfedés esetén.

I. táblázat. Olivin, ortopiroxén és klinopiroxén (továbbá gránát, földpát, kvarc, szillimanit) $\mathrm{SiO}_{4}{ }^{4-}$ tetraéder $\mathrm{Si}^{4+}$ pozícióba történő, különböző $\mathrm{H}+$ beépülésének fizikai paraméterei és értékei. $\mathrm{k}=$ kalibrációs faktor; $\rho$ = sűrűség; $\varepsilon=$ moláris integrált kioltási együttható.

Table I. Physical parameters and values of different types of $H+$ incorporation in olivine, orthopyroxene, clinopyroxene and other nominally anhydrous minerals (garnet, feldspar, quartz, sillimanite). $k=$ calibration factor; $\rho=$ density; $\varepsilon=$ molar absorption coefficient .

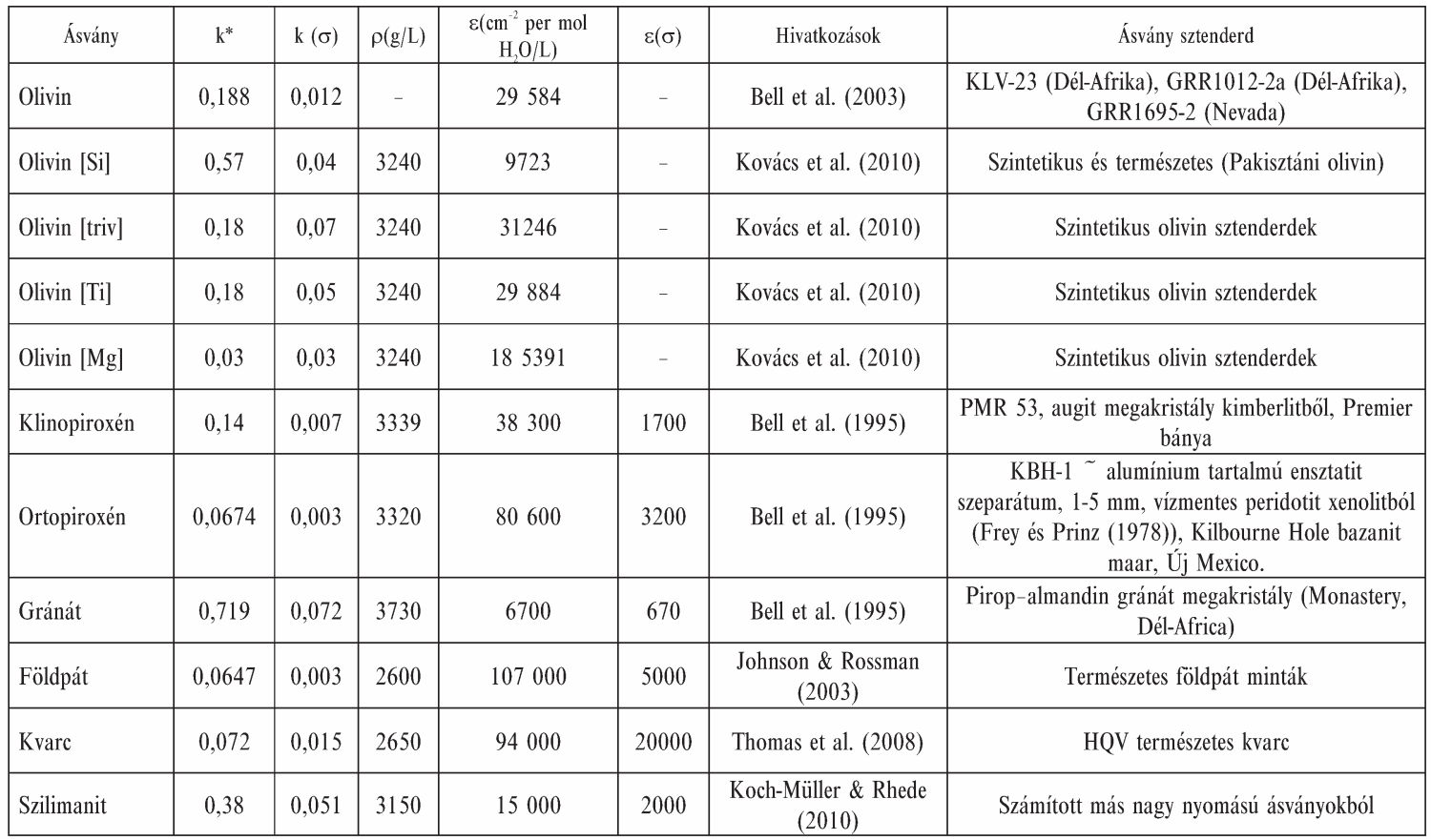


Ennek következtében a helyettesítés-specifikus kioltási együtthatók alkalmazása nem vált gyakorivá. Jelen munkánkban a leginkább elterjedt ásvány specifikus együtthatókat használjuk az olivin és a piroxének esetében.

Figyelembe véve az (1) egyenletben található tényezők bizonytalanságát és a teljes poláros abszorbancia becslésében lévő hibát, az abszolút koncentráció meghatározásában rejlô hiba minimum 5 mérésnél olivin, ortopiroxén és klinopiroxén esetén rendre $\sim 20 \%, \sim 7 \%$ és $\sim 6 \%$, (Liv et al. 2006, XiA et al. 2019, РАткó et al. 2019).

Érdemes megjegyezni, hogy a felső́köpeny xenolitokban található olivin általában igen kis szerkezeti hidroxil tartalommal rendelkezik, mivel jelentős vízvesztésen esett át a felszínre történő szállítódás során (PESLIER \& LUHR 2006, DENIS et al. 2013). Ennek oka, hogy az ismert diffúziók (pl. proton $\left(\mathrm{H}^{+}\right)$, elektron és kation diffúzió) közül a $\mathrm{H}^{+}$diffúziója következik be a legkisebb aktiválási energia mellett (pl. Novella et al. 2017). Az olvadék — a xenolit szállítása során - energiát ad át a xenolit kristályainak, gyengítve a bennük található kötéseket. Az olivinben található szerkezeti hidroxilkötés „fellazul” elôsegítve a $\mathrm{H}^{+}$diffúzióját, majd elindul az egyensúlyra való törekvés a szállító bazaltos olvadék víztartalma és az olivin víztartalma között (DEMOUCHY 2010). E folyamat hatására az olivin fokozatosan elveszti eredeti víztartalmát. РАтKó et al. (2019) kimutatta, hogy az olivin vízvesztése növekszik a szállítódás és a befogadó bazaltos olvadék húlésének idejével, azaz nagyobb vízvesztés lép fel, hogyha a xenolit lávakôzetben húl ki piroklaszthoz képest. Egyensúlyi (földköpeny) állapotban az olivin és klinopiroxén szerkezeti hidroxiltartalmának megoszlási együtthatója 10 körüli ( $D_{\text {klinopiroxén/livin }} \approx 10$ ) (XIA et al. 2019), azaz a klinopiroxén a $\mathrm{H}^{+}$koncentrációja minden esetben tízszer nagyobb az olivinhez képest. Ez az arány vélhetôen a KPR xenolitjaira is érvényes, ezáltal jól kompenzálhatjuk az esetlegesen alulbecsült szerkezeti hidroxiltartalmakat az olivin esetében.

Ismertetve az FTIR spektrometria módszert megfogalmazható az a cél, hogy a mély litoszféra NAM elegyrészeiben található szerkezeti hidroxil mennyiségének területi és mélységbeli eloszlását feltérképezzük a KárpátPannon régióban, és ennek birtokában pontosabban modellezzük a térségben lejátszódott extenzió és az extrúzió jelenségét.

\section{Eredmény}

\section{Petrográfia és geokémia}

A Persány hegység területérôl kiválasztott xenolit (PGRX1-0350) egy $7 \times 5 \times 5 \mathrm{~cm}$-es, szögletes, üde, porfíroklasztos, a spinell elrendezôdése miatt gyengén irányított szövetú, metaszomatizált lherzolit xenolit, amelynek modális összetétele a következő: olivin: $62 \%$, ortopiroxén: $18 \%$, klinopiroxén: $13 \%$, spinell: $2 \%$, amfibol: $6 \%$. Az olivin 500-1000 um átmérőjú, hipidiomorf-xenomorf alakú kristályként fordul elő. Alszemcsésedése gyakori. Az ortopiroxén mérete
200-10 $000 \mu \mathrm{m}$, szabálytalan alakú, ikresedése gyakori, és klinopiroxén, spinell és amfibol lamellákat tartalmaz. A klinopiroxén 50-2000 um nagyságú, xenomorf, ritkán ikresedik, ortopiroxén vagy amfibol lamellákat tartalmaz. Az amfibol 50-300 $\mu \mathrm{m}$ méretú, hipidiomorf kristályokat alkot, amelyek általában piroxén-spinell környezetében vagy piroxénben zárványként jelenik meg. A spinell 100-200 $\mu \mathrm{m}$ xenomorf kristályokat formál intersticiálisan. A xenolit egyes zónáiban az ortopiroxén és klinopiroxén nagy mennyiségú fluidumzárványt tartalmaz.

\section{Fourier transzformációs infravörös spektrometria}

A kiválasztott mintából készített csiszolat vastagsága $320 \mu \mathrm{m}$. A vizsgált PGR-X1-0350 xenolit vékonycsiszolatban 13 olivint, 13 ortopiroxént és 9 klinopiroxént választottunk ki elemzésre. Az abszorbanciaspektrumokon (4. ábra) a $2200-500 \mathrm{~cm}^{-1}$ közötti tartományban találhatók a Si-O-Si kötések helyeinek jellegzetes elnyelési sávjai. A 3000-2200 $\mathrm{cm}^{-1}$ között jelenik meg az atmoszferikus és a fluidumzárványban előforduló $\mathrm{CO}_{2}$ jellegzetes elnyelódési tartománya. A $3800-3100 \mathrm{~cm}^{-1}$ között hullámhossz tartományban várható az $\mathrm{OH}^{-}$és a $\mathrm{H}_{2} \mathrm{O}$ elnyelődési tartománya.

\section{Olivin}

Az olivinben az Si-O tartományon belül az 1200-500 $\mathrm{cm}^{-1}$ tartományban az elnyelődések minden ásvány esetén azonosak, míg az 2200-1600 cm $\mathrm{cm}^{-1}$ tartományban eltéró lefutásokat tapasztalunk, ami az olivin különböző kristálytani orientációjának köszönhetô (4. ábra). Minden olivinkristály esetén tapasztalunk egy aszimmetrikus elnyelődési sávot $3569 \mathrm{~cm}^{-1}$-nél, a „víz” tartományában. Ezenkívül megfigyelhetô elnyelôdés 3590 és $3525 \mathrm{~cm}^{-1}$-nél. Ritkán egy széles elnyelési sáv (3675-3150 cm ${ }^{-1}$ között) húzódik eltéró intenzitással és tartománnyal. A $3700-3600 \mathrm{~cm}^{-1}$ közötti tartományban fésús megjelenésú, kis félértékszélességú sávok csoportja azonosítható (az abszorbanciája lényegesen meghaladja a háttér értékét).

\section{Ortopiroxén}

Az ortopiroxénben a Si-O-Si elnyelődési tartományon belül (1000-500 $\mathrm{cm}^{-1}$ között) egységes profil jelenik meg, azonban a $2200-1500 \mathrm{~cm}^{-1}$ közötti tartományban eltérô elnyelődési sávok láthatók, amelyek az ásvány orientációjához kötődnek. A 3000-2800 cm-1 tartományban csak egy szemcsében tapasztalható abszorbancia. A „víz” elnyelődési tartományán belül 3 sáv különíthetô el (2960, 2930 és $\left.2860 \mathrm{~cm}^{-1}\right)$. Az OH- $\mathrm{H}_{2} \mathrm{O}$ elnyelódési tartományon belül ugyancsak 3 sáv azonosítható $\left(3590,3521\right.$ és $\left.3440 \mathrm{~cm}^{-1}\right)(5$. ábra). A 3 elnyelódési sáv közül a csökkenő hullámszámmal csökken a csúcsok intenzitása is, amely alól egy szemcse spektruma kivétel, ahol a 3400-as sáv a legintenzívebb. Ahogy az olivinekben, úgy az ortopiroxénben is jelen van 3700-3600 cm ${ }^{-1}$ között a „fésús” kis félértékszélességú sávok csoportja. 


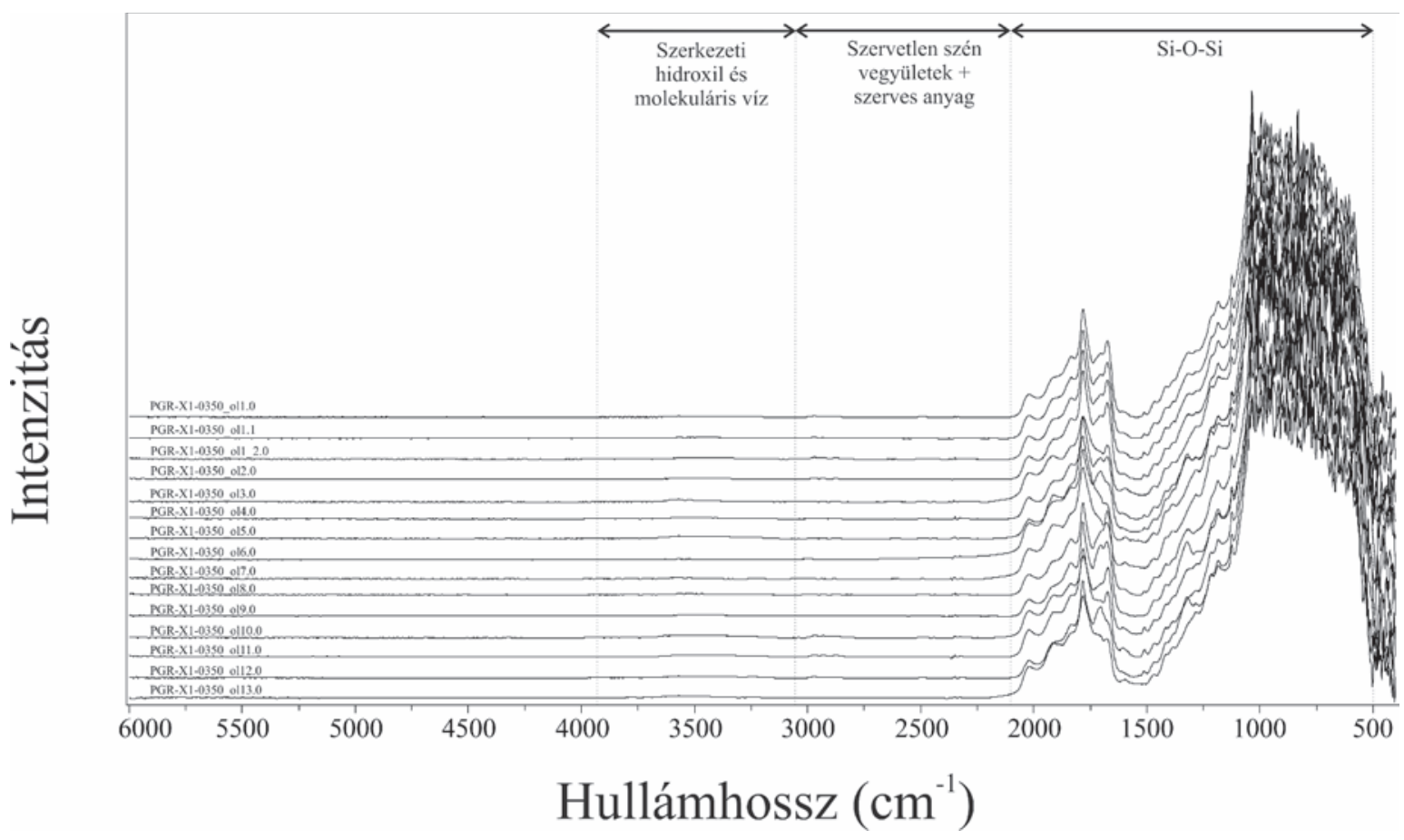

4. ábra. A vizsgált PGR-X1-0350 xenolit olivinjének teljes abszorbanciaspektruma. A spektrumon különböző elnyelődési tartományokat (Si-O-Si, szervetlen szén+szerves anyag és szerkezeti hidroxil és molekuláris víz) különithetünk el

Figure 4. Whole absorbance spectra of the olivines in the studied PGR-X1-0350 xenolith. On the spectra, different absorbance ranges (Si-O-Si bonds, inorganic carbon + organic materials and structural hydroxyl and molecular water) can be distinguished

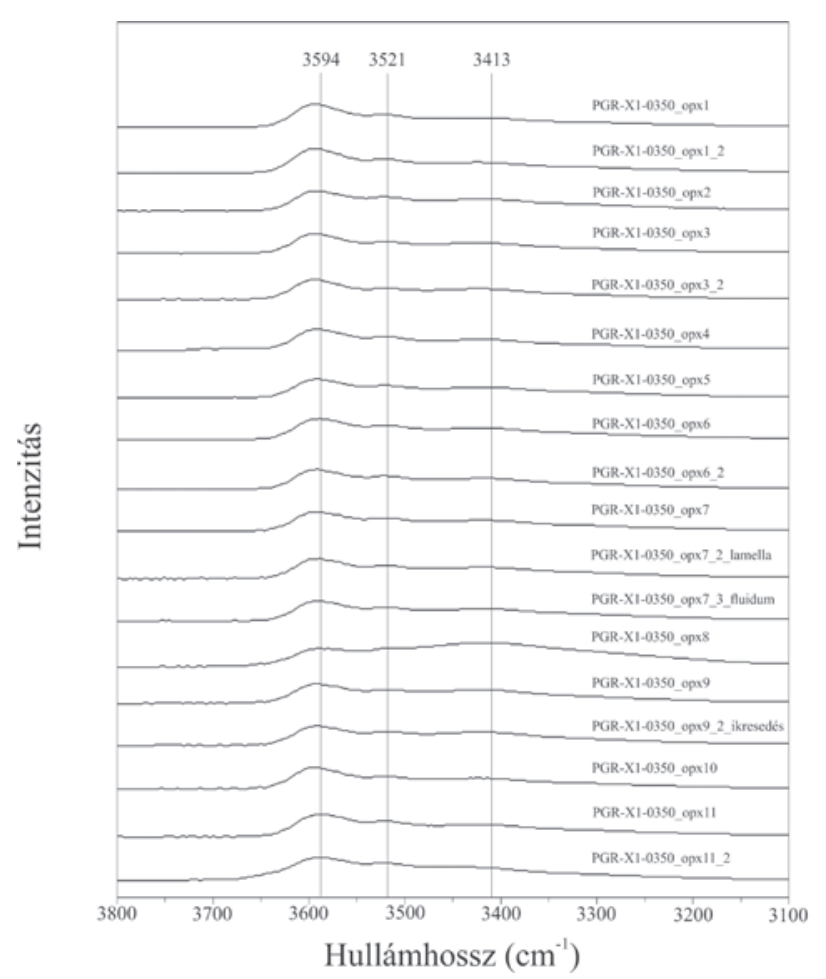

5. ábra. A vizsgált PGR-X1-0350 xenolit ortopiroxénjének szerkezeti hidroxil elnyelődési sávjai $\left(3594,3521\right.$ és $\left.3413 \mathrm{~cm}^{-1}\right)$ a $3800-3100 \mathrm{~cm}^{-1}$ tartományon belül. Az összes abszorbanciaspektrum az opx8-on kívül egységes lefutást mutat Figure 5. Structural hydroxyl absorbance peaks $\left(3594,3521\right.$ and $\left.3413 \mathrm{~cm}^{-1}\right)$ within the range of $3800-3100 \mathrm{~cm}^{-1}$ in orthopyroxene of the studied PGR-X1-0350 xenolith. Except opx8, all spectra show the same pattern

\section{Klinopiroxén}

A $2500-1400 \mathrm{~cm}^{-1}$ tartományon belül eltéró megjelenésú elnyelési sávokat figyelhetünk meg, ami a mért klinopiroxén orientációnak köszönhető. A „víz” elnyelődési tartományon belül 3 aszimmetrikus sáv mutatkozik $(3636,3525$ és $3457 \mathrm{~cm}^{-1}$ ). Minden klinopiroxénben a $3636 \mathrm{~cm}^{-1}$ a legintenzívebb sáv. A második legintenzívebb sáv (3525 $\mathrm{cm}^{-1}$ ) nem minden esetben jelenik meg (6. ábra), ami vélhetően a két szélsố sáv intenzitás növekedésének köszönhetô. A leggyengébb elnyelődés $3457 \mathrm{~cm}^{-1}$-nél tapasztalható.

\section{A szerkezeti hidroxil mennyisége a NAM elegyrészekben}

A szerkezeti hidroxil kiszámítása során (Beer-Lambert törvény szerint) nem vettük figyelembe azokat a pontméréseket, ahol alszemcsésedés, lamella, ikresedés vagy fluidumzárvány volt jelen az elemzett térfogatban. Az olivin esetében $3,27 \mathrm{~g} / \mathrm{cm}^{3}$, az ortopiroxén és klinopiroxén esetében pedig 3,32 és 3,34 g/ $\mathrm{cm}^{3}$ súrúséggel számoltunk (BELL et al. 1995), továbbá a BELL et al. (1995) és BELL et al. (2003) féle kioltási együtthatókat $\left(\varepsilon_{\mathrm{ol}}: 28.450 \mathrm{~L} \mathrm{~mol}^{-1} \mathrm{~cm}^{-2} ; \varepsilon_{\mathrm{opx}}: 80600 \mathrm{~L} \mathrm{~mol}^{-1}\right.$ $\mathrm{cm}^{-2} ; \varepsilon_{\mathrm{cpx}}: 38300 \mathrm{~L} \mathrm{~mol}^{-1} \mathrm{~cm}^{-2}$ ) használtuk. Az átlagos szerkezeti hidroxiltartalom az olivinben 4,5, az ortopiroxénben 158, a klinopiroxénben pedig 554 ppm tömegrésznek adódott. Figyelembe véve a kózetalkotó szilikátok modális részarányát (lásd a Petrográfia és geokémia alfejezetet) és az elemzett ásványokban található szerkezeti hidroxiltartalmat, a teljes xenolit szerkezeti hidroxiltartalma 39 ppm tömegrész. Az 


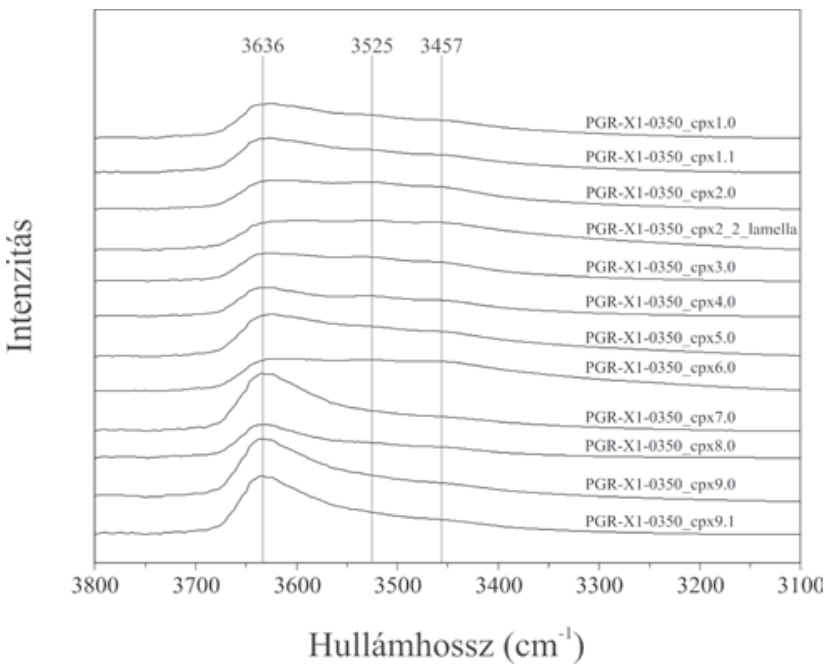

6. ábra. A vizsgált PGR-X1-0350 xenolit klinopiroxénjének szerkezeti hidroxil elnyelődési sávjai (3636, 3525 és $3457 \mathrm{~cm}^{-1}$ ) a $3800-3100 \mathrm{~cm}^{-1}$ tartományon belül. Az összes abszorbancia spektrum az cpx2_2_lamella és cpx_6.0 kívül egységes lefutást mutat

Figure 6. Structural hydroxyl absorbance peaks (3636, 3525 and $3457 \mathrm{~cm}^{-1}$ ) within the range of 3800-3100 $\mathrm{cm}^{-1}$ in clinopyroxene of the studied PGR-X1-0350 xenolith. Except cpx2_2_lamella and cpx_6.0, all spectra show the same pattern

ortopiroxén és klinopiroxén között számolt „víz” megoszlási együttható ( $\mathrm{D}^{\mathrm{cpx} / \mathrm{ppx}}$ ) 3,5, ami a XIA et al. (2019) által meghatározott „,normál” földköpeny régió $\mathrm{D}^{\mathrm{cpx} / \mathrm{opx}}=1,5-3,5$ nagyobb értékú határával azonos. A PGR-X1-0350 mintára kapott megoszlási együttható kívül esik, FALus et al. (2008) által közölt $\mathrm{D}^{\mathrm{cpx} / \mathrm{opx}}$ trendtôl (7. ábra).

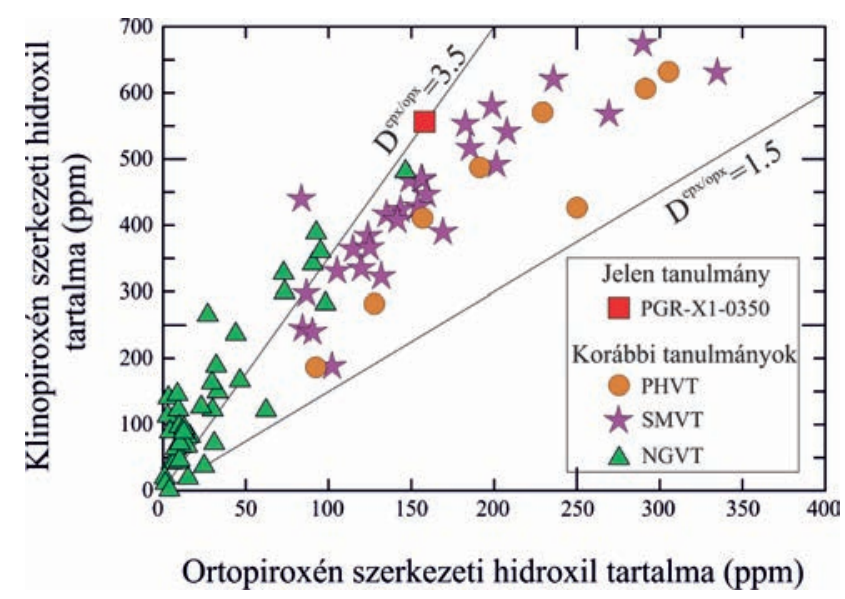

7. ábra. A KPR-ben tanulmányozott felsőköpeny xenolitokra számolt klinopiroxén és ortopiroxén szerkezeti hidroxil tartalmának megoszlási együtthatója ( $\mathrm{D}_{\text {klinopiroxén/ortopiroxén }}$ ) (PATKó et al. 2019 után módosítva). A D=1,5 és $\mathrm{D}=3,5$ megoszlási együtthatók egyenese közötti mező jelöli a „normál” köpeny tartományát (XIA et al. 2019), ahol a Persány hegységi és a stájer-medencei xenolitok mellett néhány Nógrád-Gömöri xenolit is előfordul. PHVT: Persány hegységi vulkáni terület, SMVT: Stájer-medencei vulkáni terület, NGVT: Nógrád-Gömöri vulkáni terület

Figure 7. Partition coefficient of structural hydroxyl content of clinopyroxene and orthopyroxene ( $\left.D_{\text {clinopyroxene/orthopyroxene }}\right)$ for all of the studied xenoliths of the Carpathian-Pannonian region, after PatKó et al. (2019). The area between $D=1.5$ and $D=3.5$ distribution lines define the 'normal' mantle (XIA et al. 2019), where beside xenoliths from Perşani Mountains and Styrian Basin some Nógrád-Gömör xenoliths are also fell. PHVT: Perşani Mountains Volcanic Field, SMVT: Styrian Basin Volcanic Field, NGVT: Nógrád-Gömör Volcanic Field

\section{Diszkusszió}

\section{Infravörös spektrumok értékelése}

Az olivinben a $\mathrm{H}^{+}$beépülés jellemzően a Ti-klinohumit ponthibákhoz (3569 és $3525 \mathrm{~cm}^{-1}$; BERRY et al. 2005, KovÁCs et al. 2010) és kisebb részben hidratált Mg (oktaéderes) vakanciákhoz kötődik. Az ortopiroxénben mért elnyelési sávok azonosítása még bizonytalansággal terhelt (pl. STALDER 2004; STALDER et al. 2008, STALDER \& LudWig 2007). A legnagyobb hullámszámnál (klinopiroxén: 3640 és ortopiroxén: $3590 \mathrm{~cm}^{-1}$; 5-6. ábra) megjelenó sáv a Si tetraéderes pozícióban zajló helyettesítésből származtatható, bár elképzelhető az is, hogy oktaéderes pozícióban történő csatolt $\mathrm{Na}^{+}+\mathrm{H}^{+}$helyettesítéshez kapcsolódik (pl. PurTon et al. 1997). A $3520 \mathrm{~cm}^{-1}$-nél megjelenő sáv feltételezhetően csatolt $\mathrm{Al}^{3+}+\mathrm{H}^{+}$helyettesítésnek köszönhető a tetraéderes vakanciában (KoCH-MüLLER et al. 2004). A legkisebb hullámszámnál megjelenő elnyelési sáv (ortopiroxén: 3440 és klinopiroxén: $3457 \mathrm{~cm}^{-1} ; 5-6$ a ábra) pedig az M2 oktaéderes vakanciába beépülő $\mathrm{H}^{+}$-nak tulajdonítható. A különböző NAM elegyrészekben történő $\mathrm{H}^{+}$beépülésen kívül a sztöchiometrikus vizet tartalmazó ásványok elnyelési sávjai is megjelennek (pl. amfibol, flogopit és antigorit) jellemzően a 3720-3650 cm-1 közötti spektrális régióban (pl. Della Ventura et al. 2007).

A tanulmányozott xenolitban található NAM elegyrészek szerkezeti hidroxilban viszonylag gazdagoknak tekinthetôk összevetve más, nem kratoni szubkontinentális litoszférából származó xenolitokkal (PESLIER et al. 2010). A Persány hegység eddig tanulmányozott felsőköpeny xenolitjai (FALUs et al. 2008 és jelen munka) nagy hasonlóságot mutatnak a szintén KPR peremen található Stájer-medence ultramafikus xenolitjaival (ARADI et al. 2017). A hasonlóság többek között a xenolitok nagy víztartalmában mutatkozik meg, viszonyítva a többi, KPR felsőköpeny xenolit lelőhelyről (Kisalföld, Bakony-Balaton-felvidék és NógrádGömör; KovÁcs et al. 2016, PATKó et al. 2019) származó felsőköpeny xenolit víztartalmához képest. A ,,vízgazdagság” a peremi területekre jellemző, szubkontinentális litoszferikus köpenyben számottevő mennyiségben jelenlévő, szerkezeti vizet tartalmazó ásványokon (pargasit, flogopit, apatit) túl a NAM elegyrészek vízgazdagságának is tulajdonítható (ARADI et al. 2017, SzABó et al. 2017). A Persány hegység és a Stájer-medence alatti földköpeny vízgazdasága összhangban van azzal, hogy feltételezhetően köpenyék környezetet reprezentálnak (CsONTOS et al. 1992, HORVÁTH et al. 2015). Nem hagyható figyelmen kívül azonban, hogy a KPR litoszféra kivékonyodásának a mértéke az említett keleti és nyugati peremterületek alatt kisebb, mint a központi területen (HoRvÁTH 1993, DövÉNYI 1994, ÁDÁM 1996, KovÁcs et al. 2012, BALÁzS et al. 2016), ahol a nyomáscsökkenés következtében kialakuló víz aktivitás csökkenés és hőmérséklet emelkedés eredményeként felgyorsuló diffúzió hozzájárulhatott a NAM elegyrészekben megfigyelt lényegesen kisebb szerkezeti hidroxil tartalom kialakulásához (РАTKó et al. 2019). 


\section{Effektív viszkozitás}

A Földön lejátszódó geodinamikai folyamatok különböző feszültségtereket hoznak létre, amelyekre a litoszféra válasza a reológiájának megváltoztatása. A deformáció (alszemcsésedés, deformációs ikresedés) vagy újrakristályosodás kiindulópontjai az ásványok, amelyeknek az átalakulásai kiterjednek a kőzetekre és a lokális litoszféra egyes litológiai egységeire (pl. MerciER \& NiCOLAs 1975, PIKE \& SCHWARZMAN 1977). A felsôköpenyben az olivin reagál a legérzékenyebben az új erootérre, és mint a felsőköpeny leggyakoribb ásványa (>50 tömeg\% feletti részaránnyal) meghatározza a felsőköpeny reológiáját.

$\mathrm{Az}$ olivin reológiáját jelentősen befolyásolja az ásványban található szerkezeti hidroxil mennyisége, ami az ásvány szerkezetét ,gyengíti” (KoHLSTEDT et al. 1996, DiXON et al. 2004, Li et al. 2008, PESLIER et al. 2010, FAUL et al. 2016, PADRÓN-NAVARTA \& HERMANN 2017). A folyamatot „hydrolytic weakening”-nek, azaz hidrolízis okozta gyengülésnek is nevezik. A jelenség magyarázata, hogy az ásványokban megjelenô rácshibák (vakanciák) hidratációja révén a kristályrács lokális torzulásai csökkenek, ezáltal a $\mathrm{H}^{+}$ diffúzió aktivációs energiája lecsökken és a difúzió sebessége nő. Ennek egyenes következménye, hogy a rácshibák mozgása, ezáltal a kristályok deformációja is felgyorsulhat és hatékonyabbá válhat. E gyengülés mértékére utal pl. az effektív viszkozitás, amely a NAM elegyrészek szerkezeti hidroxil tartalmának függvénye. A mélység növekedés során fellépő nyomás és hőmérséklet emelkedés csökkenő hatással van az effektív viszkozitásra. A felsôköpenyre számolt effektív viszkozitáshoz a DiXON et al. (2004) által javasolt egyenletet alkalmaztuk,

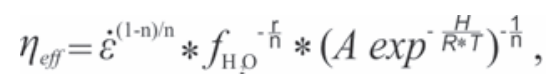

ahol $\eta_{\text {eff }}$ az effektív viszkozitás, $\dot{\varepsilon}$ a deformációs ráta, $\mathrm{n}$ a stressz kitevő, $f_{\mathrm{H} 2 \mathrm{O}}$ a víz fugacitás, r a fugacitás kitevő, A a preexponenciális állandó, $\mathrm{H}$ az entalpia, $\mathrm{R}$ az egyetemes gázállandó, T az egyensúlyi hőmérséklet. A számolás során a következő paramétereket alkalmaztuk: $n=3,5, r=1,20, A=90$, $\mathrm{R}=8,314 \mathrm{~J} /(\mathrm{mol} \mathrm{K}), \mathrm{Q}=4,80 \times 10^{5} \mathrm{~J} / \mathrm{mol}, \mathrm{V}=1,10 \times 10^{-5} \mathrm{~m}^{3} / \mathrm{mol}$. A deformációs rátát ( $\dot{\varepsilon})$ a földköpeny környezetére való tekintettel (földrengés aktív térséghez közeli) $10^{-14}$ Pas-nak vettük (DiXON et al. 2004). Ez az érték térben és időben a kéreg és a köpenylitoszféra különböző tartományaiban nagyságrendileg változik. Fontos megjegyezni, hogy a bevitt adatok pontossága (azaz a múszeres mérések feltétele) jelentős hatással van a kapott viszkozitási értékekre. DixON (2004) kimutatta, hogy a száraz és víztelített rendszer közötti viszkozitás értéke akár nagyságrendnyi különbséget mutathat. Az olivin deformációja háromféle mechanizmussal történhet: szemcsehatárdiffúzió (diffusion creep), diszlokációs kúszás (dislocation creep) és Peierls-mechanizmus. A három deformációs mechanizmus nyomás és szemcseméretfüggő, ezért az olivin szöveti vizsgálatával a deformációs események (és környezetek) nyomozhatók. E három deformációs mechanizmusból az alkalmazott modellünk elsôsorban a diszlokációs kúszás mechanizmust feltételezi tekintettel a litoszferikus köpeny fizikai állapotára.

A vizsgált PGR-X1-0350 xenolit effektív viszkozitása $4,03 \times 10^{20} \mathrm{~Pa} * \mathrm{~s}$, ami beleesik a Persány hegység 8 nádasvölgyi és bereki xenolitjára (FALus et al. 2008: 1,56×1020 $8,88 \times 10^{20} \mathrm{~Pa} * \mathrm{~s}$ ) számolt tartományba (8. ábra). A kapott érték a KPR-ben legrészletesebben tanulmányozott stájermedencei 28 xenolitra (ARADI et al. 2017) és 51 NógrádGömöri xenolitra (LIPTAI et al. 2017, 2019) számolt effektív viszkozitásértékek $1,53 \times 10^{20}-2,59 \times 10^{21} \mathrm{~Pa} * \mathrm{~s}$ (Stájermedence) és $1,70 \times 10^{20}-2,80 \times 10^{21} \mathrm{~Pa} * \mathrm{~s}$ (Nógrád-Gömör) értékek között változik (8. ábra). Az effektív viszkozitás- és számolt hőmérséklet-eredmények alapján a Persány hegység és Stájer-medence xenolitjai teljes átfedést mutatnak ( 8 . ábra). Ezzel szemben a Nógrád-Gömör xenolitjai a hőmérsékleti értékben különülnek el, nagyobb tartományt ölelnek fel és nagyobb effektív viszkozitást mutatnak, ami a lényegesen kisebb szerkezeti hidroxiltartalommal magyarázható (PAтKó et al. 2019). Mindhárom terület alatt az effektív viszkozitás a hőmérséklet növekedésével csökken (8. ábra). Ez annak köszönhető, hogy a mélység növekedésével a felsőköpeny hőmérséklete növekszik, gyengítve az ásványokban található kötéseket, ezáltal növelve a deformációra való hajlamot. A Persány hegység és Stájer-medence felsőköpenyére ez a magyarázat elfogadható, azonban a NógrádGömör esetében a vizsgált xenolitok kétharmada a nagyobb viszkozitású és kisebb hőmérsékletú mezőre esik. LIPTAI et al. (2017) köpenyxenolitok alapján három részre (északi, középsô, déli) osztotta a Nógrád-Gömör vulkáni terület litoszferikus köpenyét. A számolt adatok területi eloszlást is sejtetnek: az északi és déli területre inkább a nagyobb effektív viszkozitás a jellemző a középső terület xenolitjaihoz képest (8. ábra).

\section{Effektív viszkozitás $(\mathrm{Pa} \star \mathrm{s})$}

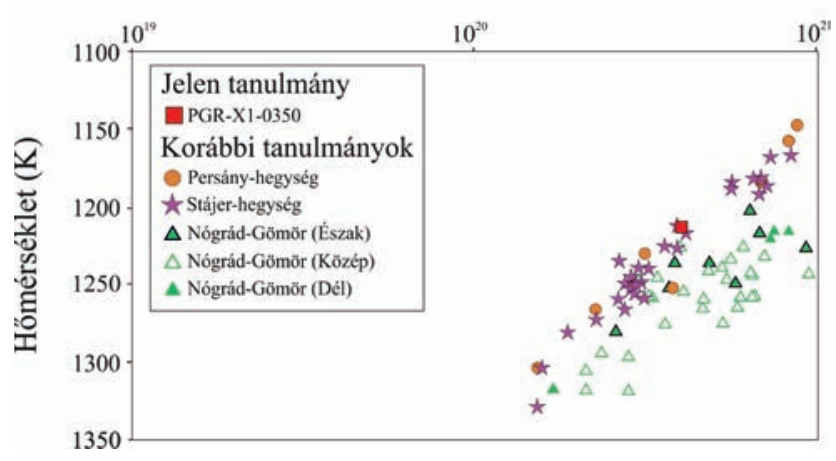

8. ábra. A Persány hegység, Stájer-medence és Nógrád-Gömör xenolitjainak effektív viszkozitása $\left(\mathrm{Pa}^{*} \mathrm{~s}\right)$ az egyensúlyi hőmérséklet $(\mathrm{K})$ függvényében. Mindhárom xenolitlelőhely egységes negatív korrelációt mutat a hőmérséklettel. A Persány hegység és Stájer-medence xenolitjai egy trendvonalra esnek. A Nógrád-Gömöri xenolitok nagyobb hömérsékletük miatt egy zónában önálló trendet és részleges területi elkülönülést mutatnak

Figure 8. Effective viscosity $\left(\mathrm{Pa}^{*} \mathrm{~s}\right)$ vs. equilibrium temperature $(\mathrm{K})$ for xenoliths from the Perşani Mountains, Styrian Basin and Nógrád-Gömör. All three xenolith locations show the same negative trend with increasing temperature. Perşani Mountains and Styrian Basin xenoliths follow the same line, Nógrád-Gömör xenoliths, due to their higher temperature, are distributing in a wider range with partial areal pattern 


\section{Fajlagos vezetóképesség}

A felsőköpeny két leggyakoribb ásványa (olivin és piroxén) a földköpenyben félvezetôként viselkedhet, amit az ásványokban található $\mathrm{Fe}^{2+}, \mathrm{Fe}^{3+}$ és szerkezeti hidroxilként beépülő $\mathrm{H}^{+}$-re vezethető vissza. A xenolitok kiváló lehetôséget biztosítanak az in situ vezetốképesség számolására, amelyek eredményeivel ellenőrizni lehet a magnetotellurikus szondázás során kapott eredményeket (SELWAY et al. 2014, 2015). A kísérleti munkák döntố többsége az olivin fajlagos vezetôképességét igyekezett meghatározni a hômérséklet és nyomás függvényében (WANG et al. 2006, NovelLa et al. 2017). Az első modellek a teljes kőzet fajlagos ellenállását kizárólag az olivin alapján becsülték meg (Yoshino \& Katsura 2013). Azonban újabb, részletesebb geokémiai modellek figyelembe veszik a felsőköpenyben található többi ásványt (ortopiroxén, klinopiroxén, amfibol, spinell) is (pl. Jones et al. 2009, 2011; FulLEA 2017), továbbá a kis mennyiségben jelen lévő mafikus (pl. Ni et al. 2011, Miller et al. 2015, LAUMONiER et al. 2017) vagy karbonátos olvadék jelenlétét is (SIFRÉ et al. 2014).

A FulLea (2017) által javasolt számolási módszer paramétereit használva (minimum vezetôképesség, entalpia, hőmérséklet, Fe-koncentráció, ásványra jellemző fizikai-kémiai állandók, szerkezeti hidroxil tartalom) a PGR-X1-0350 xenolit NAM szilikátjainak fajlagos ellenállása: olivin $109 \Omega \mathrm{m}$, ortopiroxén $111 \Omega \mathrm{m}$, klinopiroxén 9 $\Omega \mathrm{m}$, teljes xenolitra kiszámolva pedig $67 \Omega \mathrm{m}$ (9. ábra). Ezek az értékek beleesnek a Persány hegység 8 nádasvölgyi és bereki xenolitjára (FALUS et al. 2008) számolt fajlagos ellenállási tartományba (olivin: 39-200 $\Omega \mathrm{m}$; ortopiroxén: $10-163 \Omega \mathrm{m}$; klinopiroxén: 2-22 $\Omega \mathrm{m}$; teljes xenolit: $35-153 \Omega \mathrm{m}$ ). Összehasonlításképp a Stájer-medence és Nógrád-Gömör alatti köpeny litoszférára számolt fajlagos ellenállásadatok a következó tartományokat ölelik fel: Stájer-medence: olivin: $58-415 \Omega \mathrm{m}$, ortopiroxén: $50-371$ $\Omega \mathrm{m}$, klinopiroxén: $5-32 \Omega \mathrm{m}$, teljes xenolit: $36-317$, és Nógrád-Gömör: olivin: 74-1011 $\Omega \mathrm{m}$, ortopiroxén: 83$2021 \Omega \mathrm{m}$, klinopiroxén: 8-589 $\Omega \mathrm{m}$, a teljes xenolit: 49 $925 \Omega \mathrm{m}$ (II. táblázat). A bemutatott adatok szerint az olivin és az ortopiroxén fajlagos ellenállása hasonló a nagyobb vezetốképességú klinopiroxénéhez képest. A három vulkáni terület litoszferikus köpenyét összehasonlítva megállapítható, hogy a Persány hegység és a Stájermedence xenolitjai egyaránt egy szúk fajlagos vezetôképesség eloszlást mutatnak adott hőmérséklet (nyomás) tartományra (9. ábra). E két peremi területhez képest a nógrád-gömöri felsőköpeny xenolitok fajlagos ellenállásértéke jóval szélesebb tartományba esik és kisebb egyensúlyi hőmérsékleti (mélység) változékonyságot mutat a vezetôképesség függvényében. A jellemzett fajlagos ellenállásban mutatkozó különbség a nógrád-gömöri xenolitok vízszegénységéhez, valamint a Persány hegység, illetve a Stájer-medence liroszferikus köpenyének a vízgazdagságához köthetô, mivel nincs lényegi különbség a felsôköpeny Fe-tartalmában (VASELLI et al. 1995, SzABÓ et al. 2004, FALUS et al. 2008, ArADI et al. 2017).
Fajlagos ellenállás $(\Omega \mathrm{m})$

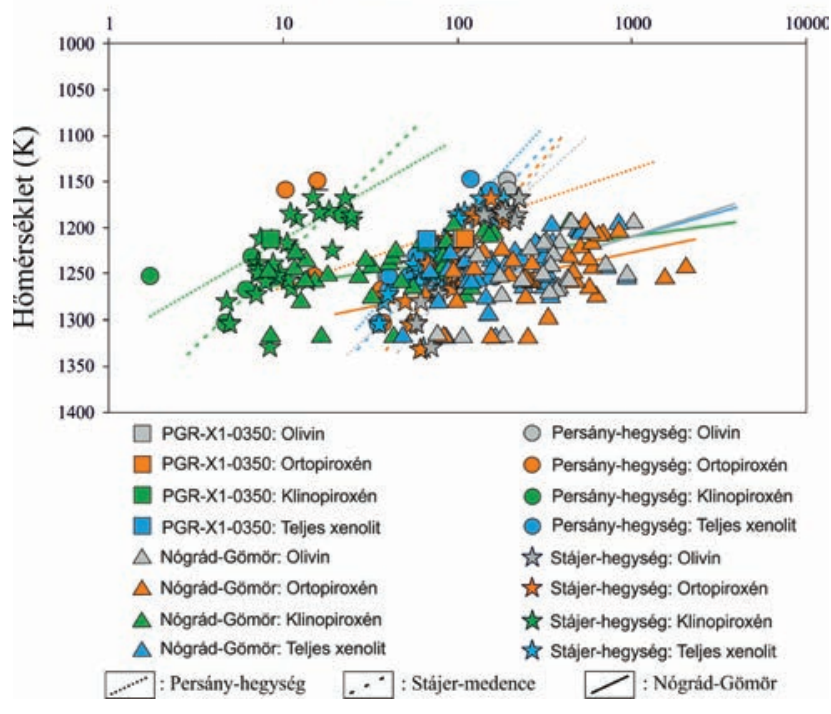

9. ábra. A Persány hegységi, stájer-medencei és nógrád-gömöri xenolitok kőzetalkotó ásványainak (olivin, ortopiroxén és klinopiroxén) és a teljes xenolit fajlagos elektromos ellenállása $(\Omega \mathrm{m})$ a hỏmérséklet $(\mathrm{K})$ függvényében. Olivin és ortopiroxén fajlagos ellenállása hasonló, a klinopiroxén ellenben kisebb fajlagos ellenállás értékkel rendelkezik. A Persány hegység és Stájer-medence xenolitjainak ásványai hasonló trendet rajzolnak ki, míg a nógrád-gömöri xenolitok ásványai eltérő trendet formálnak

Figure 9. Specific electrical resistivity $(\Omega m)$ of rock forming minerals (olivine, orthopyroxene and clinopyroxene) and of bulk xenoliths in function of equilibrium temperature (K) for xenoliths from the Perşani Mountains, Styrian Basin and Nógrád-Gömör. Olivin and orthopyroxene have similar specific electrical resistivity, whereas clinopyroxene shows low values. Rock forming minerals and bulk xenoliths form the Perşani Mountains and Styrian Basin depict the same trends, whereas those from Nógrád-Gömör distribute along distinct trends

\section{Szeizmikus sebesség}

Ha ismert a köpenyxenolit modális ásványos összetétele és az ásványok kémiai összetétele, akkor kiszámolható a xenolitra vonatkozó átlagos primer (Vp) és szekunder (Vs) hullámterjedési sebesség (pl. JAMES et al. 2004, HACKER \& Abers 2004, PesLIER et al. 2010, KléBESZ et al. 2015). Az adatok egymással való összevethetősége érdekében egy átlagos alkáli bazaltos területre vonatkoztatott $\mathrm{dT} / \mathrm{dp}$ görbét alkalmaztunk. Fontos megjegyezni, hogy JAMES et al. (2004) módszere izotróp közegként kezeli a köpenyt, így ezen adatok nem feltétlenül egyeztethetők össze a visszaszórt elektrondiffrakciós (EBSD) adatokból számolt szeizmikus anizotrópia értékekkel (pl. FALus et al. 2007, ARADI et al. 2017, LIPTAI et al. 2019). A különböző mélységből származó xenolitokra kapott hullámterjedési sebesség olyan oszlopot rajzol ki, amely több (3D tesztre kiterjeszthető) geofizikai módszer ellenőrzésére alkalmas (pl. szeizmikus tomográfia; RAWLINSON et al. 2006). Ilyen összehasonlítás során a geofizikai eredmények (szeizmikus tomográfia) összevethetốk a xenolitokból meghatározott Vp és Vs hullámterjedési sebességtartománnyal (pl. Kovács et al. 2018). Bár a névlegesen vízmentes ásványok szerkezeti hidroxil tartalma nincs jelentős hatással a primer és szekunder hullámok terjedési sebességére, azonban jelentôsen lecsökkentik az adott kôzet olvadáspontját. A részleges 
II. táblázat. Összefoglaló táblázat a $\mathrm{H}^{+}$olivinbe, ortopiroxénbe és klinopiroxénbe történő beépülésről. Az irodalmi adatokon kívül feltüntettük a jelen munkában megfigyelt sávokat

Table II. Summary of $\mathrm{H}^{+}$incorporation into olivine, orthopyroxene and clinopyroxene. Data acquired in this paper were also added to it

\begin{tabular}{|c|c|c|c|}
\hline Elnyelödés fajtája & Hullámhossz $\left(\mathrm{cm}^{-1}\right)$ & Irodalom & Jelen munka $\left(\mathrm{cm}^{-1}\right)$ \\
\hline \multicolumn{4}{|c|}{ Olivin } \\
\hline Atmoszferikus $\mathrm{H}_{2} \mathrm{O}$ (recés megjelenés) & $>3700$ & Libowitzky (2006) & - \\
\hline Olivin átalakulása során megjelenö talk & 3709 & Miller et al. (1987) & - \\
\hline Olivin átalakulása során megjelenö talk & 3685 & Miller et al. (1987) & - \\
\hline Olivin átalakulása során megjelenő talk & 3645 & Miller et al. (1987) & - \\
\hline Forsteritben történő $\mathrm{H}^{+}$beépülés alacsony $\mathrm{Si}$ aktivitás mellett & 3612 & Balan et al. (2010) & - \\
\hline Forsteritben történő $\mathrm{H}^{+}$beépülés nagy $\mathrm{Si}$ aktivitás mellett & 3600 & Balan et al. (2010) & - \\
\hline Forsteritben történő $\mathrm{H}^{+}$beépülés alacsony $\mathrm{Si}$ aktivitás mellett & 3580 & Balan et al. (2010) & 3590 \\
\hline Ti-klinohumit & 3572 & $\begin{array}{l}\text { Berry et al. (2005), Kovács et } \\
\text { al. (2010) }\end{array}$ & - \\
\hline Forstritben történő $\mathrm{H}^{+}$és $\mathrm{Ti}^{4+}$ beépülés & 3572 & Balan et al. (2010) & - \\
\hline Forsteritben történő $\mathrm{H}^{+}$beépülés alacsony $\mathrm{Si}$ aktivitás mellett & 3566 & Balan et al. (2010) & \\
\hline Ti-klinohumit & 3525 & $\begin{array}{l}\text { Berry et al. (2005), Kovács et } \\
\text { al. (2010) }\end{array}$ & 3525 \\
\hline Forsteritben történő $\mathrm{H}^{+}$és $\mathrm{Ti}^{4+}$ beépülés & 3525 & Balan et al. (2010) & - \\
\hline Forsteritben történő $\mathrm{H}^{+}$beépülés alacsony $\mathrm{Si}$ aktivitás mellett & 3480 & Balan et al. (2010) & - \\
\hline $\mathrm{H}^{+}$és $\mathrm{M}^{3+}$ egyidejü beépülése ( $\mathrm{pl} . \mathrm{B}^{3+}, \mathrm{Al}^{3+}, \mathrm{Sc}^{3+}, \mathrm{V}^{3+}$ ) & $3400-3300$ & Berry et al. (2007) & - \\
\hline Forsteritben történő $\mathrm{H}^{+}$és $\mathrm{M}^{3+}$ kation beépülés & 3350 & Balan et al. (2010) & - \\
\hline Forsteritben történő $\mathrm{H}^{+}$és $\mathrm{M}^{3+}$ kation beépülés & 3320 & Balan et al. (2010) & - \\
\hline $\mathrm{H}^{+}$beépülés oktaéderes $(\mathrm{Mg})$ vakanciába & 3230 & $\begin{array}{l}\text { Berry et al. (2005), Kovács et } \\
\text { al. (2010) }\end{array}$ & - \\
\hline Forsteritben történő $\mathrm{H}^{+}$beépülés nagy $\mathrm{Si}$ aktivitás mellett & 3220 & Balan et al. (2010) & - \\
\hline Forsteritben történő $\mathrm{H}^{+}$beépülés nagy $\mathrm{Si}$ aktivitás mellett & 3160 & Balan et al. (2010) & - \\
\hline \multirow[t]{2}{*}{ Szerves anyag } & $<3100$ & & $2960,2930,2860$ \\
\hline & & & - \\
\hline \multicolumn{4}{|c|}{ Ortopiroxén } \\
\hline Szubmikron amfibol v. flogopit jelenléte & $3675-3695$ & $\begin{array}{l}\text { Demouchy } 2010 \text {, Kovács et al. } \\
2012\end{array}$ & - \\
\hline Trivalens kation $+\mathrm{H}^{+}$együttes beépülés & 3600 & Stalder \& Skogby 2002 & 3590 \\
\hline Trivalens kation $+\mathrm{H}^{+}$együttes beépülés & 3525 & Stalder \& Skogby 2002 & 3521 \\
\hline Trivalens kation $+\mathrm{H}^{+}$együttes beépülés & 3420 & Stalder \& Skogby 2002 & 3440 \\
\hline \multicolumn{4}{|c|}{ Klinopiroxén } \\
\hline Szubmikron amfibol v. flogopit jelenléte & $3675-3695$ & $\begin{array}{l}\text { Demouchy } 2010 \text {, Kovács et al. } \\
2012\end{array}$ & - \\
\hline Trivalens kation $+\mathrm{H}^{+}$együttes beépülés & 3600 & Della Ventura et al. (2007) & 3636 \\
\hline Trivalens kation $+\mathrm{H}^{+}$együttes beépülés & 3525 & Della Ventura et al. (2007) & 3525 \\
\hline Trivalens kation $+\mathrm{H}^{+}$együttes beépülés & 3420 & Della Ventura et al. (2007) & 3457 \\
\hline
\end{tabular}

olvadás során képződő olvadék viszont lecsökkenti különösen a szekunder hullámok terjedési sebességét (pl. CHANTEL et al. 2016). A JAMES et al. (2004) módszere (szükséges paraméterek: adiabatikus nyomás modulus, nyírási modulus, Grüneisen parameter, nyomás, hőmérséklet, sűrűség, hőtágulási együttható, olivin fayalit-tartalom $[\mathrm{Fe} / \mathrm{Mg}+\mathrm{Fe}]$, ortopiroxén ferroszillit-tartalom [Fe/Mg+Fe]) alapján a vizsgált PGRX1-0350 xenolit Vp és Vs hullámterjedési sebessége $\mathrm{Vp}=$ $7,81 \mathrm{~km} / \mathrm{s}$ és $\mathrm{Vs}=4,38 \mathrm{~km} / \mathrm{s}$, a $\mathrm{Vp} / \mathrm{Vs}$ hányados pedig 1,78 (10. ábra). FALus et al. (2008) által közölt Persány hegységi xenolit adatokból számolt Vp és Vs sebességtartomány 7,83-7,92 km/s és 4,43-4,48 km/s, a hányadosuk tartománya $1,76-1,77$, ami szúk sebességtartományként értelmez- hető. A Stájer-medencében a Vp és Vs értékek 7,7-7,90 $\mathrm{km} / \mathrm{s}$ és 4,38-4,53 km/s közötti tartományt fednek le, hányadosuk 1,74-1,81; a Nógrád-Gömör Vp és Vs értékei 7,77-7,95 km/s és 4,33-4,49 km/s között mozognak, hányadosuk 1,74-1,80 közötti (10. ábra; III. táblázat). Mindhárom vulkáni terület xenolitjaira számolt hullámterjedési sebesség csökken az egyensúlyi hőmérséklet-növekedés függvényében (10. ábra, a és b).

Érdemes továbbá megjegyezni, hogy a PGR-X1-0350 xenolitban az amfibol részaránya 6 tömeg\%, ezzel szemben FALus et al. (2008) Persány hegységi xenolitjai amfibolmentesek. A Stájer-medence xenolitjaiban az amfibol gyakori, és részaránya 16 tömeg\%-ot is elérhet (ARADI et al. 

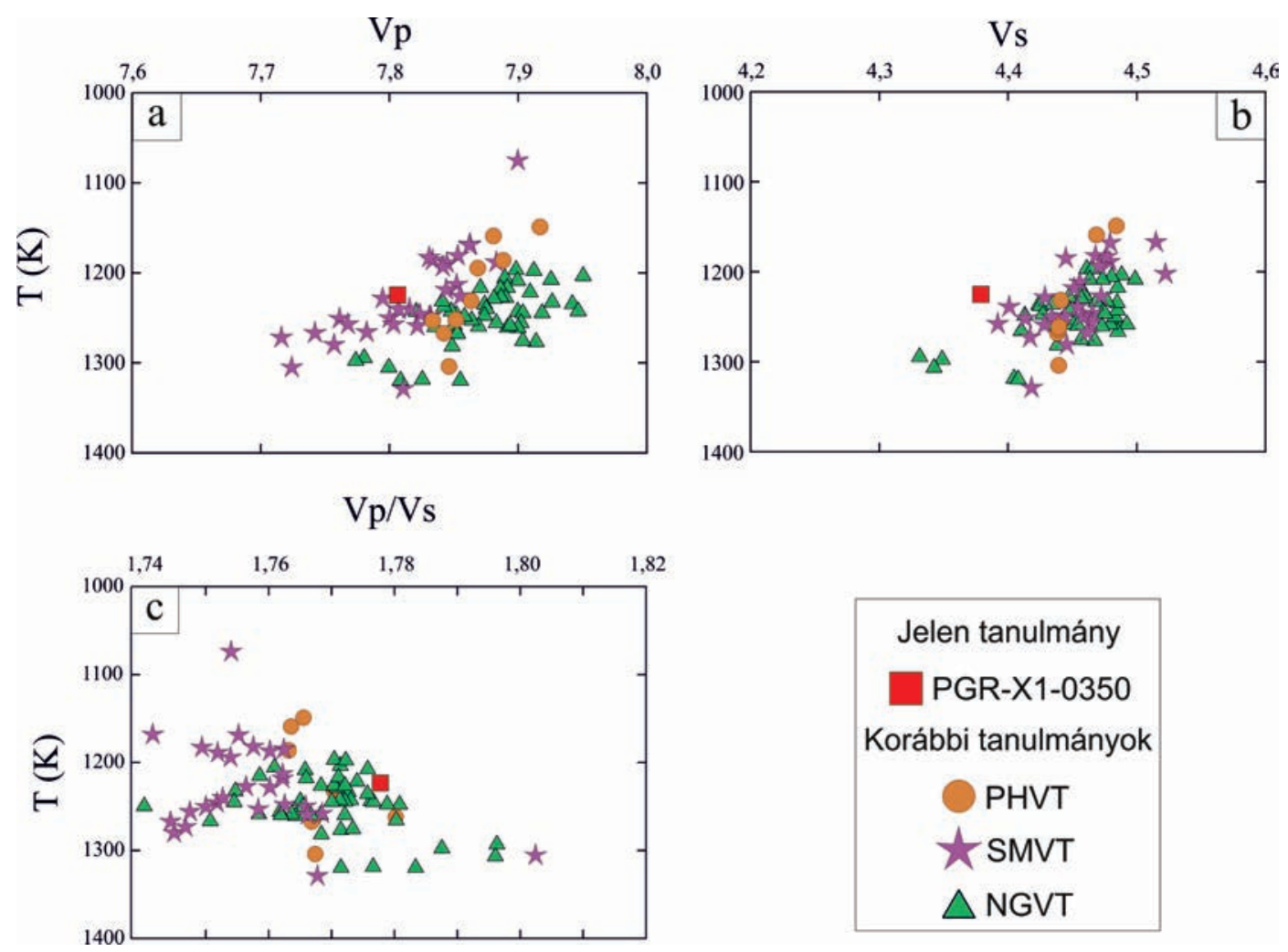

10. ábra. A Persány hegység, Stájer-medence és Nógrád-Gömör xenolitjaira számolt primer és szekunder szeizmikus hullámterjedési sebesség (Vp, Vs) az egyensúlyi hőmérsékleti adatok (K) függvényében. a) A Stájer-medence és a Nógrád-Gömör xenolitjai széles Vp tartományban jelennek meg, míg a Persány hegység xenolitjai szűk Vp tartományba esnek. b) A Vs hullámterjedési sebesség adatai az összes xenolitra egymást átfedve egy halmazban jelennek meg. c) A Persány hegység xenolitjainak Vp/Vs sebesség aránya szük sávban jelennek meg, elválasztva a kisebb sebességhányadossal jellemezhető Stájer-medence xenolitjait a nagyobb Vp/Vs hányadosú nógrád-gömöri xenolitoktól. PHVT: Persány hegységi vulkáni terület, SMVT: Stájer-medencei vulkáni terület, NGVT: NógrádGömöri vulkáni terület

Figure 10. Calculated primer and seconder seismic wave velocity (Vp, Vs) vs. equilibrium temperature (K) for Perşani Mountains, Styrian Basin and Nógrád-Gömör mantle xenoliths. a) The Styrian Basin and Nógrád-Gömör xenoliths demonstrate a wide range in Vp velocity compared to the Perşani Mountains xenoliths showing only a narrow Vp distribution. b) All xenoliths, regardless their localities, show a common cluster of Vs velocity. c) Data points of Vp/Vs ratio for the Perşani Mountain form a narrow range separating the low Vp/Vs ratio xenoliths from the Styrian Basin from the high Vp/Vs ratio Nógrád-Gömör xenoliths. PHVT: Perşani Mountains Volcanic Field, SMVT: Styrian Basin Volcanic Field, NGVT: Nógrád-Gömör Volcanic Field.

2017). Feltételezhetően az amfiboltartalom okozhatja, azt, hogy a vizsgált PGR-X1-0350 xenolit Vp hullámterjedési sebessége a Stájer-medence xenolitjai (ARADI et al. 2017) által kirajzolt mezőre esik és nem a Persány hegység (FALuS et al. 2008) amfibolmentes xenolitjainak trendjére (10. ábra, a). A vizsgált Nógrád-Gömör xenolitjai (LIPTAI et al. 2017) ritkán és alárendelt mennyiségben tartalmaznak amfibolt (max. 2 tömeg\%-ban), és olivinben gazdagabbak a másik két vulkáni terület litoszferikus köpenyéhez képest (SzABÓ et al. 2004); a legnagyobb Vp sebesség értékeket (>8 km/s) erre a litoszferikus köpenyre számoltuk (10. ábra, a). A Vs hullámterjedési sebességben a különböző vulkáni területek xenolitjai egységes képet mutatnak, a három terület nem különíthetô el egymástól (10. ábra, b).

A Vp/Vs hullámterjedési sebességarányok — egyensúlyi hốmérséklet relációban a Persány hegységi PGR-X10350 xenolit a nógrád-gömöri xenolitok mezejébe esik. Ellenben Persány hegység többi xenolitja (FALUs et al. 2008) az egyensúlyi hőmérséklettől független trendet jelöl ki elválasztva a kisebb sebesség hányadossal jellemezhető Stájer- medence xenolitjait a nagyobb Vp/Vs aránnyal definiálható nógrád-gömöri xenolitoktól (10. ábra, c).

Érdemes megjegyezni, hogy a köpenymodellek kizárólag a szilárd fázisokat veszik számításba, kizárva a fluidum/ olvadék jelenlétét. Ha a modellek figyelembe vennék a fluidumok szerepét, elképzelhető, hogy a tárgyalt Vp adatok eloszlása kismértékben negatív irányba eltolódna a Vp hullámok a kis érzékenysége miatt. A Vp hullámhoz képest a Vs hullám érzékeny a fluidum/olvadék jelenlétére, és a sebessége fluidum-/olvadékgazdag közegben jelentősen lecsökken. Ezek alapján elképzelhető, hogy a KPR keleti és nyugati peremén található Persány hegység és Stájer-medence litoszferikus köpenye a központi régió vulkáni területeihez (Bakony-Balaton-felvidék, Kisalföld) képest kisebb Vs sebességértékekkel rendelkezik. A Persány hegység és Stájer-medence xenolitjaira számolt Vs-csökkenés a hőmérséklet (mélység) függvényében mindkét területen feltételezhető szubdukálódó lemezből felszabaduló fludiumokhoz kötődhet. A Nógrád-Gömör területen, bár több metaszomatikus esemény — beleértve a wehrlitesedést — is lejátszódott 
III. táblázat. A PGR-X1-0350 tesztxenolitra, Persány hegység, (FALus et al. 2008), Stájer-medence (ARADI et al. 2017) és Nógrád-Gömör (LiPTAI et al. 2017) felsőköpeny xenolitjaira számolt effektív viszkozitás, fajlagos ellenállás és szeizmikus hullámterjedési sebesség. A táblázatban feltüntettük PoPA et al. (2012) Vráncsa- zónában mért szeizmikus adatait is

Table III. Calculated effective viscosity, conductivity and seismic wave velocity values for xenolith PGR-X1-0350 and xenoliths from Perşani Mountains (FALUS et al. 2008), Styrian Basin (ARADI et al. 2017) and Nógrád-Gömör (LIPTAI et al. 2017). Seismic velocity results from the Vrancea area are from PoPa et al. (2012)

\begin{tabular}{|l|c|c|c|c|c|c|}
\hline & PGR-X1-0350 & $\begin{array}{c}\text { Persányi-hegység (Falus } \\
\text { et al. 2008; jelenlegi } \\
\text { munka) }\end{array}$ & $\begin{array}{c}\text { Persányi-hegység (Falus et } \\
\text { al. 2008; Kovács et al. } \\
\text { 2018) }\end{array}$ & $\begin{array}{c}\text { Vráncsa-zóna } \\
\text { Popa et al. 2012 }\end{array}$ & $\begin{array}{c}\text { Stájer-medence (Aradi et } \\
\text { al., 2017) }\end{array}$ & $\begin{array}{c}\text { Nógrád-Gömör (Liptai } \\
\text { et al., 2017) }\end{array}$ \\
\hline Effektív viszkozitás $\left(\mathrm{Pa} \times s^{-1}\right)$ & $4,03 \times 10^{20}$ & $1,56 \times 10^{20}-8,88 \times 10^{20}$ & $6,47 \times 10^{19}-9,13 \times 10^{20}$ & n.a. & $1,53 \times 10^{20}-2,59 \times 10^{21}$ & $1,70 \times 10^{20}-2,80 \times 10^{20}$ \\
\hline $\begin{array}{l}\text { Fajlagos ellenállás (olivin) } \\
(\Omega \mathrm{m})\end{array}$ & 109 & $39-200$ & $37-228$ & n.a. & $58-415$ & $74-1011$ \\
\hline $\begin{array}{l}\text { Fajlagos ellenállás } \\
\text { (ortopiroxén) }(\Omega \mathrm{m})\end{array}$ & 111 & $10-163$ & $29-181$ & n.a. & $50-317$ & $83-2021$ \\
\hline $\begin{array}{l}\text { Fajlagos ellenálás } \\
\text { (klinopiroxén) }(\Omega \mathrm{m})\end{array}$ & 9 & $2-22$ & $3-24$ & n.a. & $5-32$ & $8-589$ \\
\hline $\begin{array}{l}\text { Fajlagos ellenállás (teljes } \\
\text { xenolit) }(\Omega \mathrm{m})\end{array}$ & 67 & $35-153$ & $10-69$ & n.a. & $36-317$ & $49-925$ \\
\hline $\begin{array}{l}\text { Szeizmikus hullámterjedési } \\
\text { sebesség }(V p ; \mathrm{km} / \mathrm{s})\end{array}$ & 7,89 & $7,83-7,91$ & $7,78-7,88$ & $7,01-8,28$ & $7,76-7,90$ & $7,77-7,95$ \\
\hline $\begin{array}{l}\text { Szeizmikus hullámterjedési } \\
\text { sebesség (Vs; } \mathrm{km} / \mathrm{s})\end{array}$ & 4,46 & $4,43-4,48$ & $4,42-4,47$ & $4,13-4,75$ & $4,23-4,51$ & $4,33-4,49$ \\
\hline $\begin{array}{l}\text { Szeizmikus hullámterjedési } \\
\text { sebesség aránya }(\mathrm{V} \text { /Vs) }\end{array}$ & 1,78 & $1,76-1,77$ & $1,76-1,79$ & n.a. & $1,74-1,81$ & $1,74-1,80$ \\
\hline
\end{tabular}

(LIPTAI et al. 2017), ezek geokémiai hatása nem okozott akkora reológiai változást, mint a Stájer-medence és Persány hegység alatti litoszférában.

A Persány hegységtől nem messze található Vráncsazóna nagy magnitúdójú (>6.0 a Richter-skála szerint) földrengéseinek tanulmányozásáról számos geofizikai munka született (pl. Tondi et al. 2009, BARON \& Morelli 2017). A szeizmikus tomográfia adatokat $(\mathrm{Vp}=7,01-8,28$ és $\mathrm{Vs}=$ 4,13-4,75 km s$~^{-1}$ (PoPA et al. 2012) összevetve a Persány hegységi xenolitokból számolt geofizikai eredményekkel ( $\mathrm{Vp}=7,73-7,92 \mathrm{~km} \mathrm{~s}^{-1}$ és Vs=4,33-4,52 $\mathrm{km} \mathrm{s}^{-1}$ (KovÁcs et al. 2018) kijelenthetô, hogy Vp és Vs sebességtartományok átfednek (III. táblázat). Azonban a xenolit adatokból számolt paraméterek szúkebb intervallumba esnek, mint a szeizmikus tomográfia alapján kapott eredmények. Tehát a xenolitok jó becslést adnak a litoszferikus köpenyrégió szeizmikus hullámterjedési sebességére. PoPA et al. (2012) geofizikai adatainak nagyobb szórása valószínúleg annak köszönhető, hogy eredményeik tartalmazzák a korábban említett fluidum/olvadék komponenst is.

\section{Következtetés}

A bemutatott FTIR módszer segítségével egyszerúen, gyorsan és kis költséggel juthatunk olyan eredményekhez a felsőköpeny geokémiai és geodinamikai kutatásában, amivel más módszerek adatai ellenőrizhetôk. A példaként bemutatott (PGR-X1-0350) Persány hegységi Grujuról származó felsőköpeny xenolitra kapott szerkezeti hidroxiltartalom jól illeszkedik a Kárpát-Pannon régióból származó felsőköpeny xenolitok eddigi mérési eredményeihez (Persány hegység, Stájer-medence és Nógrád-Gömör). Az FTIR mérések alapján, a KPR keleti (Persány hegység) és nyugati (Stájer-medence) peremterületeirôl vizsgált xenolitok nagyobb víztarta- lommal rendelkeznek, mint a nógrád-gömöri (és a központi elhelyezkedésú) társaik. A vizsgált xenolit megerôsíti a Persány hegység alatti köpeny „,víz”-gazdagságát, ami vélhetően a szubdukálódó/delaminálódó lemez okozta metaszomatózisnak köszönhető. A jövőbeli numerikus és analóg modellekben lényeges lehet az ilyen, területi és mélységbeli heterogenitások figyelembevétele. További fontos tanulság, hogy a felsôköpeny „víz”-tartalma és így a reológiája időben változhat, amit modellezés során figyelembe kellene venni. A bemutatott módszerek lehetôséget adnak arra, hogy ezen ismeretek birtokában a jelenlegi modelleket tovább pontosítsuk.

A Kárpát-Pannon régió geodinamikai fejlődésének megértéséhez a felsőköpeny NAM elegyrészekben található szerkezeti hidroxil koncentráció meghatározása alapvető adatokat szolgáltat a mélylitoszféra fajlagos vezetôképességének és viszkozitásának meghatározásához. Ezek közül a fajlagos vezetőképesség megkönnyíti a mély magnetotellurikus szondázások eredményeinek földtani értelmezését, ami hozzájárulhat a litoszféra lemezek háromdimenziós szerkezetének jobb megismeréséhez.

Az effektív viszkozitás függ a NAM elegyrészek víztartalmától, hőmérséklettől, deformációs rátától és a kőzetek olvadáspontjától (ami szintén a kőzet teljes ,,víz”-tartalmának függvénye), ezért fontos paraméter a litoszféra kinematikáját taglaló numerikus és analóg modellekben. A bemutatott Persány hegységi tesztxenolit effektív viszkozitásértéke nagy hasonlóságot mutat a Stájer-medence xenolitjaiból számított értékekkel, ami szintén megerősíti a geológiai párhuzamot a két terület között.

Jelen dolgozat demonstrálja a felsőköpeny xenolitjait alkotó NAM elegyrészek víztartalmának jelentőségét, az adatok sokrétú felhasználását. A víztartalom méréséhez ideális FTIR módszer olyan adatokat szolgáltat a xenolitokról, amelyek geofizikai méréseket kiegészítve a korszerú geodinamikai modellezések eszenciális alkotói. 


\section{Köszönetnyilvánítás}

A szerzők köszönik az LRG tagok közremúködését, különösen PÁLos Zsófia önzetlen segítségét. Az FT-IR mérések kivitelezésében nyújtott segítségért köszönet illeti KESJÁR Dórát (MTA CSFK FGI).

LANGE Thomas Pieter köszöni az Emberi Erőforrások Minisztériuma ÚNKP-18-3 kódszámú Új Nemzeti Kiválóság Programjának támogatását, amely hozzájárult a dolgozat elkészítéséhez.

ARADI László köszöni az ELTE Felsőoktatási Intézmé- nyi Kiválósági Program (1783-3/2018/FEKUTSRAT) nevú pályázat támogatását, amely az Emberi Erőforrások Minisztériuma támogatásával valósult meg. A kézirat elkészültét támogatta az MTA CSFK Lendület Pannon LitH $_{2}$ Oscope Kutatócsoport.

A cikk az LRG 97. publikációja, amely a MTA CSFK GGI és a Lendület Pannon $\mathrm{LitH}_{2}$ Oscope Kutatócsoportjával együttmúködésben készült.

A szerzők köszönik BALÁzs Attilának és az Anonim bírálóknak a kézirat olvasása során tett javításaikat és hasznos javaslataikat/tanácsaikat.

\section{Irodalom -References}

Ackermann, L., Cemič, L. \& Langer, K. 1983: Hydrogarnet substitution in pyrope: a possible location for "water" in the mantle. Earth and Planetary Science Letters 62, 208-214. https://doi.org/10.1016/0012-821x(83)90084-5

ÁdÁM, A. 1996: Regional magnetotelluric (MT) anisotropy in the Pannonian Basin (Hungary). — Acta Geodaetica of Geophysica Hungaricae 31, 191-216. https://doi.org/10.1556/ageod.39.2004.4.5

Aradi, L. E., Hidas, K., Kovács, I. J., Tommasi, A., Klébesz, R., Garrido, C. J. \& Szabó, Cs. 2017: Fluid-Enhanced Annealing in the Subcontinental Lithospheric Mantle Beneath the Westernmost Margin of the Carpathian-Pannonian Extensional Basin System. Tectonics 36, 2987-3011. https://doi.org/10.1002/2017tc004702

BAI, Q. \& KoHLSTEDT, D. L. 1992: Substantial hydrogen solubility in olivine and implications for water storage in the mantle. — Nature 357, 672-674. https://doi.org/10.1038/357672a0

BAI, Q. \& KOHLSTEDT, D. L. 1993: Effects of chemical environment on the solubility and incorporation mechanism for hydrogen in olivine. - Physics and Chemistry of Minerals 19, 460-471. https://doi.org/10.1007/bf00203186

Balan, E., Ingrin, J., Delattre, S., Kovács, I. \& Blanchard, M. 2011: Theoretical infrared spectrum of OH-defects in forsterite. European Journal of Mineralogy 23, 285-292. https://doi.org/10.1127/0935-1221/2011/0023-2090

Balázs, A., Matenco, L., Magyar, I., Horváth, F. \& Cloetingh, S. A. P. L. 2016: The link between tectonics and sedimentation in backarc basins: New genetic constraints from the analysis of the Pannonian Basin. — Tectonics 35, 1526-1559. https://doi.org/ 10.1002/2015TC004109

Bali, E., Zanetti, A., Szabó, C., Peate, D. W. \& Waight, T. E. 2008: A micro-scale investigation of melt production and extraction in the upper mantle based on silicate melt pockets in ultramafic xenoliths from the Bakony-Balaton Highland Volcanic Field (Western Hungary). — Contributions to Mineralogy and Petrology 155, 165-179. https://doi.org/10.1007/s00410-007-0234-4

BARON, J. \& Morelli, A. 2017: Full-waveform seismic tomography of the Vrancea, Romania, subduction region. — Physics of the Earth and Planetary Interiors 273, 36-49. http://dx.doi.org/10.1016/j.pepi.2017.10.009

Bell, D. R., Ihinger, P. D. \& Rossman, G. D. 1995: Quantitative analysis of trace OH in garnet and pyroxenes. - American Mineralogist 80, 465-474. https://doi.org/10.2138/am-1995-5-607

Bell, D. R., Rossman, G. R., Maldener, J., Endisch, D. \& Rauch, F. 2003: Hydroxide in olivine: A quantitative determination of the absolute amount and calibration of the IR spectrum. - Journal of Geophysical Research: Solid Earth 108, B2. https://doi.org/ $10.1029 / 2001 \mathrm{jb} 000679$

Bell, D.R., Rossman, G.R. \& Moore, R.O. 2004: Abundance and Partitioning of OH in a High-pressure Magmatic System: Megacrysts from the Monastery Kimberlite, South Africa. — Journal of Petrology 45, 1539-1564. https://doi.org/10.1093/petrology/egh015

Berkesi, M., Guzmics, T., Szabó, C., Dubessy, J., Bodnar, R.J., Hidas, K. \& Ratter, K. 2012: The role of $\mathrm{CO}_{2}$-rich fluids in trace element transport and metasomatism in the lithospheric mantle beneath the Central Pannonian Basin, Hungary, based on fluid inclusions in mantle xenoliths. — Earth and Planetary Science Letters 331-332, 8-20. https://doi.org/10.1016/j.epsl.2012.03.012

Berry, A. J., Hermann, J., O'NeILl, H. S. C. \& Foran, G. J. 2005: Fingerprinting the water site in mantle olivine. - Geology 33, 869. https://doi.org/10.1130/g21759.1

Berry, A. J., O'NeILl, H. S. C., Hermann, J. \& ScotT, D. R. 2007: The infrared signature of water associated with trivalent cations in olivine. — Geochimica et Cosmochimica Acta 70, A49. https://doi.org/10.1016/j.gca.2006.06.1569

Biró, T., Kovács, I. J., Király, E., Falus, Gy., Karátson, D., Bendó, Zs., Fancsik, T. \& Sándorné, J. K. 2016: Concentration of hydroxyl defects in quartz from various rhyolitic ignimbrite horizons: results from unpolarized micro-FTIR analyses on unoriented phenocryst fragments. — European Journal of Mineralogy 28, 313-327. https://doi.org/10.1127/ejm/2016/0028-2515

Chalot-Prat, F. \& Boullier, A.-M. 1998: Metasomatism in the subcontinental mantle beneath the Eastern Carpathians (Romania): new evidence from trace element geochemistry. — Contributions to Mineralogy and Petrology 129, 284-307. https://doi.org/ $10.1007 / \mathrm{s} 004100050338$

Chantel, J., Manthilake, G., Andrault, D., Novella, D., Yu, T. \& Wang, Y. 2016: Experimental evidence supports mantle partial melting in the asthenosphere. - Science Advances 2, e1600246. https://doi.org/10.1126/sciadv.1600246

Csontos, L., Nagymarosy, A., Horváth, F. \& Kováč, M. 1992: Tertiary evolution of the Intra-Carpathian area: a model. Tectonophysics 208, 221-241. https://doi.org/10.1016/0040-1951(92)90346-8 
Della Ventura, G., Oberti, R., Hawthorne, F. C. \& Bellatreccia, F. 2007: FTIR spectroscopy of Ti-rich pargasites from Lherz and the detection of $\mathrm{O}_{2}$-at the anionic $\mathrm{O}_{3}$ site in amphiboles. — American Mineralogist 92/10, 1645-1651. https://doi.org/10.2138/ am.2007.2199

DEMOUCHY, S. 2010: Diffusion of hydrogen in olivine grain boundaries and implications for the survival of water-rich zones in the Earth's mantle. — Earth and Planetary Science Letters 295, 305-313. https://doi.org/10.1016/j.eps1.2012.09.034

Denis, C. M. Demouchy, S. \& Shaw, C. S. 2013: Evidence of dehydration in peridotites from Eifel Volcanic Field and estimates of the rate of magma ascent. - Journal of Volcanology and Geothermal Research 258, 85-99. https://doi.org/10.1016/ j.jvolgeores.2013.04.010

Dixon, E., Dixon, T. H., Bell, D. R. \& Malservisi, R. 2004: Lateral variation in upper mantle viscosity: role of water. — Earth and Planetary Science Letters 222, 451-467. https://doi.org/10.1016/j.eps1.2004.03.022

DöVÉNYI P. 1994. Geofizikai vizsgálatok a Pannon-medence litoszférafejlődésének megértéséhez. — Candidate thesis, Hungarian Academy of Sciences, Budapest, 127 p.

Downes, H., Seghedi, I., Szakács, A., Dobosi, G., James, D.E., Vaselli, O., Rigby, I. J., Ingram, G. A., Rex, D. \& Pécskay, Z. 1995: Petrology and geochemistry of late Tertiary/Quaternary mafic alkaline volcanism in Romania. — Lithos 35, 65-81. https://doi.org/ 10.1016/0024-4937(95)91152-y

Falus, Gy., Szabó, Cs. \& Vaselli, O. 2000: Mantle upwelling within the Pannonian Basin: evidence from xenolith lithology and mineral chemistry. - Terra Nova 12, 295-302. https://doi.org/10.1046/j.1365-3121.2000.00313.x

Falus, Gy., Tommasi, A., Ingrin, J. \& SZABÓ, Cs. 2008: Deformation and seismic anisotropy of the lithospheric mantle in the southeastern Carpathians inferred from the study of mantle xenoliths. - Earth and Planetary Science Letters 272/1-2, 50-64. https://doi.org/ 10.1016/j.eps1.2008.04.035

FALUS, GY., TOMMASI, A. \& SOUSTELLE, V. 2011: The effect of dynamic recrystallization on olivine crystal preferred orientations in mantle xenoliths deformed under varied stress conditions. — Journal of Structural Geology 33, 1528-1540. https://doi.org/10.1016/ j.jsg.2011.09.010

Faul, U. H., Cline, C. J., David, E. C., BerRY, A. J. \& JACKSON, I. 2016: Titanium-hydroxyl defect-controlled rheology of the Earth's upper mantle. - Earth and Planetary Science Letters 452, 227-237. https://doi.org/10.1016/j.eps1.2016.07.016

FREY, F. A., \& PRINZ, M. 1978: Ultramafic inclusions from San Carlos, Arizona: petrologic and geochemical data bearing on their petrogenesis.—Earth and Planetary Science Letters 38, 129-176. https://doi.org/10.1016/0012-821X(78)90130-9

FULLEA, J. 2017: On joint modelling of electrical conductivity and other geophysical and petrologica lobservables to infer the structure of the lithosphere and underlying upper mantle. - Surveys in Geophysics 38, 963-1004. https://doi.org/10.1007/s10712-017-9432-4

Green, D. H., Hibberson, W. O., KovÁCs, I. \& Rosenthal, A. 2010: Water and its influence on the lithosphere-asthenosphere boundary. - Nature 467, 448-451. https://doi.org/10.1038/nature09369

GuZmics, T., Zajacz, Z., KodolánYI, J., Halter, W. \& Szabó, Cs. 2008: LA-ICP-MS study of apatite- and K feldspar-hosted primary carbonatite melt inclusions in clinopyroxenite xenoliths from lamprophyres, Hungary: Implications for significance of carbonatite melts in the Earth's mantle. — Geochimica et Cosmochimica Acta 72, 1864-1886. https://doi.org/10.1016/j.gca.2008.01.024

Harangi, Sz., Sági, T., Seghedi, I. \& NTAflos, T. 2013: Origin of basaltic magmas of Perşani volcanic field, Romania: A combined whole rock and mineral scale investigation. — Lithos 180, 43-57. http://dx.doi.org/10.1016/j.lithos.2013.08.025

HACKER, B. R. \& ABERS, G. A. 2004: Subduction factory 3: an Excel worksheet and macro for calculating the densities, seismic wave speeds, and $\mathrm{H}_{2} \mathrm{O}$ contents of minerals and rocks at pressure and temperature. - Geochemistry, Geophysics, Geosystems $\mathbf{5}$. https://doi.org/10.1029/2003GC000614

HidAs, K., FALUS, GY., SZABÓ, Cs., SZABÓ, P.J., KovÁCS, I. \& FÖLDES, T. 2007: Geodynamic implications of flattened tabular equigranular textured peridotites from the Bakony-Balaton Highland Volcanic Field (Western Hungary). — Journal of Geodynamics 43, 484-503. https://doi.org/10.1016/j.jog.2006.10.007

Hidas, K., Guzmics, T., Szabó, C., Kovács, I., Bodnár, R. J., Zajacz Z., Nédli Zs., Vaccari L. \& Perucchi, A. 2010: Coexisting silicate melt inclusions and $\mathrm{H}_{2} \mathrm{O}$-bearing, $\mathrm{CO}_{2}$-rich fluid inclusions in mantle peridotite xenoliths from the Carpathian-Pannonian region (central Hungary). - Chemical Geology 274, 1-18. https://doi.org/10.1016/j.chemgeo.2010.03.004

Horváth, F. 1993: Towards a mechanical model for the formation of the Pannonian basin. Tectonophysics 226, $333-357$. https://doi.org/10.1016/0040-1951(93)90126-5

Horváth, F., Musitz, B., Balázs, A., Végh, A., Uhrin, A., Nádor, A., Koroknai, B., Pap, N., Tóth, T. \& Wórum, G. 2015: Evolution of the Pannonian basin and its geothermal resources. Geothermics 53, 328-352. https://doi.org/10.1016/j.geothermics.2014.07.009

Ingrin, J., Kovács, I., Deloule, E., Balan, E., Blanchard, M., Kohn, S. C. \& Hermann, J. 2014: Identification of hydrogen defects linked to boron substitution in synthetic forsterite and natural olivine. - American Mineralogist 99, 2138-2141. https://doi.org/ 10.2138/am-2014-5049

Inoue, T., Weidner, D. J., Northrup, P. A. \& PArise, J. B. 1998: Elastic properties of hydrous ringwoodite ( -phase) in $\mathrm{Mg}_{2} \mathrm{SiO}_{4}$. — Earth and Planetary Science Letters 160, 107-113. https://doi.org/10.1016/s0012-821x(98)00077-6

JAMES, D. E., BoyD, F. R., SChutt, D., Bell, D. R. \& CARLSON, R. W. 2004: Xenolith constraints on seismic velocities in the upper mantle beneath southern Africa. — Geochemistry, Geophysics, Geosystems 5. https://doi.org/10.1029/2003gc000551

Jones, A. G., Evans, R. L. \& EATON, D. W. 2009: Velocity-conductivity relationships for mantle mineral assemblages in Archean cratonic lithosphere based on a review of laboratory data and Hashin-Shtrikman extremal bounds. — Lithos 109, $131-143$. https://doi.org/10.1016/j.lithos.2008.10.014

Jones, A. G., FulleA, J., Evans, R. L. \& Muller, M. R. 2012: Water in cratonic lithosphere: calibrating laboratorydetermined models of electrical conductivity of mantle minerals using geophysical and petrological observations. - Geochemistry, Geophysics, Geosystems 13. https://doi.org/10.1029/2012gc004055

Johnson, E. A. \& Rossman, G. R. 2003: The concentration and speciation of hydrogen in feldspars using FTIR and ${ }^{1} \mathrm{H}$ MAS NMR spectroscopy. — American Mineralogist 88, 901-911. https://doi.org/10.2138/am-2003-5-620 
Karato, S. 1990: The role of hydrogen in the electrical conductivity of the upper mantle. - Nature 347, $272-273$. https://doi.org/10.1038/347272a0

KARAto, S-I., PATERSOAn, M. S. \& FitZGerald, J. D. 1986: Rheology of synthetic olivine aggregates: influence of grain size and water. — International Journal of Rock Mechanics and Mining Sciences \& Geomechanics Abstracts, 24, A8. https://doi.org/10.1016/01489062(87)91296-4

Klébesz, R., Gráczer, Z., Szanyi, Gy., Liptai, N., Kovács, I., Patkó, L., Pintér, Zs., Falus, Gy., Wesztergom, V. \& Szabó, Cs. 2015: Constraints on the thickness and seismic properties of the lithosphere in an extensional setting (Nógrád-Gömör Volcanic Field, Northern Pannonian Basin). — Acta Geodaetica et Geophysica 50, 133-149. https://doi.org/10.1007/s40328-014-0094-0

Koch-MüLler, M., MatsyuK, S. S. \& WIRTH, R. 2004: Hydroxyl in omphacites and omphacitic clinopyroxenes of upper mantle to lower crustal origin beneath the Siberian platform. — American Mineralogist 89, 921-931. https://doi.org/10.2138/am-2004-0701

Kohlstedt, D. L., Keppler, H. \& Rubie, D. C. 1996: Solubility of water in the $\alpha, \beta$ and $\gamma$ phases of $\left(\mathrm{Mg}, \mathrm{Fe}_{2} \mathrm{SiO}_{4}\right.$. - Contributions to Mineralogy and Petrology 123, 345-357. https://doi.org/10.1007/s004100050161

Kovács, I., Hermann, J., O’neill, H. St. C., Gerald, J. F., Sambridge, M. \& Horváth, G. 2008: Quantitative absorbance spectroscopy with unpolarized light: Part II. Experimental evaluation and development of a protocol for quantitative analysis of mineral IR spectra. —American Mineralogist 93, 765-778. https://doi.org/10.2138/am.2008.2656

Kovács, I., O'NeILl, H. S. C., HeRmAnN, J. \& HAURI, E. H. 2010: Site-specific infrared O-H absorption coefficients for water substitution into olivine. - American Mineralogist 95, 292-299. https://doi.org/10.2138/am.2010.3313

Kovács, I., Demény, A. CzupPon, Gy., LÉCuyer, C., Fourel, F., XiA, Q.-K. Liu, J., Pintér, Zs., KirÁly, E., TörÖK, K., SzABÓ, Á., Deloule, E., Falus, Gy., Fancsik, T., Zajacz, Z., SÁndorné Kovács, J. \& Udvardi, B. 2016: Water concentrations and hydrogen isotope compositions of alkaline basalt-hosted clinopyroxene megacrysts and amphibole clinopyroxenites: the role of structural hydroxyl groups and molecular water. — Contributions to Mineralogy and Petrology 171, 38. https://doi.org/10.1007/s00410-016-1241-0

Kovács, I., Falus, Gy., Stuart, G., Hidas, K., Szabó, Cs., Flower, M. F. J., Hegedús, E., Posgay, K. \& Zilahi-Sebess, L. 2012: Seismicanisotropy and deformation patterns in upper mantle xenoliths from the central Carpathian-Pannonian region: Asthenospheric flowas a driving force for Cenozoic extension and extrusion? — Tectonophysics 514-517, 168-179. https://doi.org/ 10.1016/j.tecto.2011.10.022

Kovács, I. J., Patkó, L., Falus, Gy., Aradi, L. E., Szanyi, Gy., Gráczer, Z. \& Szabó, Cs. 2018: Upper mantle xenoliths as sources of geophysical information: the Perşani Mts. area as a case study. — Acta Geodaetica et Geophysica 53, 415-438. https://doi.org/ 10.1007/s40328-018-0231-2

Laumonier, M., Farla, R., Frost, D. J., Katsura, T., Marquardt, K., Bouvier, A. S. \& Baumgartner, L. P. 2017: Experimental determination of melt interconnectivity and electrical conductivity in the upper mantle. _ Earth and Planetary Science Letters $\mathbf{4 6 3}$, 286-297. https://doi.org/10.1016/j.epsl.2017.01.037

Lemaire, C., KoHn, S. C. \& BRooKer, R. A. 2004: The effect of silica activity on the incorporation mechanisms of water in synthetic forsterite: a polarised infrared spectroscopic study. - Contributions to Mineralogy and Petrology 147, 48-57. https://doi.org/10.1007/s00410-003-0539-X

Li, Z. X. A., Lee, C. T. A., Peslier A. H., Lenardic A. \& Mackwell, S. J. 2008: Water contents in mantle xenoliths from the Colorado Plateau and vicinity: Implications for the mantle rheology and hydration-induced thinning of continental lithosphere. — Journal of Geophysical Research: Solid Earth 113, B9. https://doi.org/10.1029/2007jb005540

LiBowitzky, E. 2006: 2. The Structure of Hydrous Species in Nominally Anhydrous Minerals: Information from Polarized IR Spectroscopy. - In KeppleR, H. \& SMYth J. R. (eds): Water in Nominally Anhydrous Minerals. 62, Berlin, Boston: De Gruyter. 2952. https://doi.org/10.1515/9781501509476-006

Libowitzky, E. \& Rossman, G. R. 1996: Principles of quantitative absorbance measurements in anisotropic crystals. — Physics and Chemistry of Minerals 23, 319-327 https://doi.org/10.1007/bf00199497

LibowitZky, E. \& Rossman, G. R. 1997: An IR absorption calibration for water in minerals. - American Mineralogist, 82, $1111-1115$. https://doi.org/10.2138/am-1997-11-1208

Liptai, N., Patkó, L, Kovács, I. J., Hidas, K., Pintér, Zs., Jeffries, T., Zajacz, Z., O’reilly, S.Y., Griffin, W.L., Pearson, N. J. \& SzABó, Cs. 2017: Multiple metasomatism beneath the Nógrád-Gömör Volcanic Field (Northern Pannonian Basin) revealed by upper mantle peridotite xenoliths. — Journal of Petrology 58, 1107-1144. https://doi.org/10.1093/petrology/egx048

Liptai, N., Hidas, K., Tommasi, A., Patkó, L., Kovács, I. J., Griffin, W. L., O’Reilly, S. Y., Pearson, S. Y. \& Szabó, Cs. 2019: Lateral and vertical heterogeneity in the lithospheric mantle at the northern margin of the Pannonian Basin reconstructed from peridotite xenolith microstructures. — Journal of Geophysical Research: Solid Earth 124, https://doi.org/10.1029/2018jb016582

LiU, X. I., O'NEILL, H. S. C. \& BERRY, A. J. 2006: The effects of small amounts of $\mathrm{H}_{2} \mathrm{O}, \mathrm{CO}_{2}$ and $\mathrm{Na}_{2} \mathrm{O}$ on the partial melting of spinel lherzolite in the system $\mathrm{CaO}-\mathrm{MgO}-\mathrm{Al}_{2} \mathrm{O}_{3}-\mathrm{SiO}_{2} \pm \mathrm{H}_{2} \mathrm{O} \pm \mathrm{CO}_{2} \pm \mathrm{Na}_{2} \mathrm{O}$ at $1.1 \mathrm{GPa}$. Journal of Petrology 47, $409-434$. https://doi.org/10.1093/petrology/egi081

Lu, R. \& KeppleR, H. 1997: Water solubility in pyrope to 100 kbar. - Contributions to Mineralogy and Petrology 129, $35-42$. https://doi.org/10.1007/s004100050321

Luff, P., SEghedI, I. \& DuCEA, M. 2015: Subcreted oceanic crust melting beneath the Southeastern-Carpathians: evidence from garnet pyroxenite xenoliths from Quaternary basalts of the Perşani Mts. - Mineralogia, Special Papers, 43, 63-64.

MACKWELL, S. J. \& KoHLSTEDT, D. L. 1990: Diffusion of hydrogen in olivine: implications for water in the mantle. — International Journal of Rock Mechanics and Mining Sciences \& Geomechanics Abstracts 28, A78. https://doi.org/10.1016/0148-9062(91)92297-c

MALDENER, J., RAUCH, F., GaVRANIC, M. \& BERAN, A. 2001: OH absorption coefficients of rutile andcassiterite deduced from nuclear reactionanalysis and FTIR spectroscopy. — Mineralogy Petrology 71, 21-29. https://doi.org/10.1007/s007100170043

Mandeville, C. W., Webster, J. D., Rutherford, M. J., Taylor, B. E., Timbal, A. \& Faure, K. 2002: Determination of molar 
absorptivities for infrared absorption bands of $\mathrm{H}_{2} \mathrm{O}$ in andesitic glasses. — American Mineralogist 87, 813-821. https://doi.org/ 10.2138/am-2002-0702

Matveev, S., O’neill, H. S. C., Ballhaus, C., Taylor, W. R. \& Green, D. H. 2001: Effect of Silica Activity on OH- IR Spectra of Olivine: Implications for Low-aSiO 2 Mantle Metasomatism. — Journal of Petrology 42, 721-729. https://doi.org/10.1093/petrology/42.4.721

MERCIER, J. C. C. \& Nicolas, A. 1975: Textures and fabrics of upper-mantle peridotites as illustrated by xenoliths from basalts. — Journal of Petrology 6, 454-487. https://doi.org/10.1093/petrology/16.1.454

Miller, K. J., Montési, L. G. \& ZHU, W. L. 2015: Estimates of olivine-basaltic melt electrical conductivity using a digital rock physics approach. —Earth and Planetary Science Letters 432, 332-341. https://doi.org/10.1016/j.eps1.2015.10.004

Miller, G. H., Rossman, G. R. \& Harlow, G. E. 1987: The natural occurrence of hydroxide in olivine. - Physics and Chemistry of Minerals 14, 461-472. https://doi.org/10.1007/bf00628824

Ni, H., KePPler, H. \& BeHRENS, H. 2011: Electrical conductivity of hydrous basaltic melts: implications for partial melting in the upper mantle. - Contributions to Mineralogy and Petrology 162, 637-650. https://doi.org/10.1007/s00410-011-0617-4

Novella, D., Jacobsen, B., Weber, P. K., Tyburczy, J. A., Ryerson, F. J. \& Du Frane, W. L. 2017: Hydrogen self-diffusion in single crystal olivine and electrical conductivity of the Earth's mantle. — Scientific Reports 7, 5344. https://doi.org/10.1038/s41598-017-05113-6

PAdrón Navarta, J. A. \& Hermann, J. 2017: A subsolidus olivine water solubility equation for the Earth's upper mantle. — Journal of Geophysical Research: Solid Earth 122, 9862-9880. https://doi.org/10.1002/2017jb014510

Panaiotu, C. G., Jicha, B. R., Singer, B. S., T,ugui, A., Seghedi, I., Panaiotu, A. G. \& Necula, C. 2013: ${ }^{40}$ Ar ${ }^{39}$ Ar chronology and paleomagnetism of Quaternary basaltic lavas from the Perşani Mountains (East Carpathians). — Physics of the Earth and Planetary Interiors 221, 1-14. https://doi.org/10.1016/j.pepi.2013.06.007

PATERSON, M. S. 1982: The determination of hydroxyl by infrared absorption in quartz glasses and similar materials. — Bulletin de Minéralogie 105, 20-29.

Patkó, L., Liptai, N., Kovács, I. J., Aradi, L. E., Xia, Q-K., Ingrin, J., Mihály, J., O’Reilly, S. Y., Griffin, W. L., Wesztergom, V. \& SzABÓ, Cs. 2019: Extremely low structural hydroxyl contents in upper mantle xenoliths from the Nógrád-Gömör Volcanic Field (northern Pannonian Basin): Geodynamic implications and the role of post-eruptive re-equilibration. — Chemical Geology 507, 2341. https://doi.org/10.1016/j.chemgeo.2018.12.017

Peslier, A .H. \& LuHr, J. F. (2006) Hydrogen loss from olivines in mantle xenoliths from Simcoe (USA) and Mexico: mafic alkalic magma ascent rates and water budget of the sub-continental lithosphere. — Earth and Planetary Science Letters 242, 302-319. https://doi.org/10.1016/j.epsl.2005.12.019

Peslier, A. H., Woodland, A. B., Bell, D. R. \& Lazarov, M. 2010: Olivine water contents in the continental lithosphere and the longevity of cratons. - Nature 467, 78-81. https://doi.org/10.1038/nature09317

Pike, J. N. \& Schwarzman, E. C. 1977: Classification of textures in ultramafic xenoliths. — The Journal of Geology 85, 49-61. https://doi.org/10.1086/628268

Plank, T., Kelley, K. A., Zimmer, M. M., Hauri, E. H. \& Wallace, P. J. 2013: Why do mafic arc magmas contain 4wt\% water on average? — Earth and Planetary Science Letters 364, 168-179. https://doi.org/10.1016/j.epsl.2012.11.044

Popa, M., Radulian, M., SzAKÁcs, A., Seghedi, I., \& ZAHARIA, B. 2012: New seismic and tomography data in the southern part of the Harghita Mountains (Romania, Southeastern Carpathians): connection with recent volcanic activity. — Pure and Applied Geophysics 169, 1557-1573. https://doi.org/10.1007/s00024-011-0428-6

Purton, J. A., Allan, N. L. \& Blundy, J. D. 1997: Calculated solution energies of heterovalent cations in forsterite and diopside: implications for trace element partitioning. — Geochimica et Cosmochimica Acta 61, 3927-3936. https://doi.org/10.1016/s0016-7037(97)00198-1

Rauch, M. \& KePPler, H. 2002: Water solubility in orthopyroxene. — Contributions to Mineralogy and Petrology 143, 525-536. https://doi.org/10.1007/s00410-002-0365-6

Rawlinson, N., READING A. M. \& KENNETT, B. L. 2006: Lithospheric structure of Tasmania from a novel form of teleseismic tomography. - Journal of Geophysical Research: Solid Earth 111, B2. https://doi.org/10.1029/2005J B0038 03

Rossman, G. R. \& Aines, R. D. 1991: The hydrous components in garnets: Grossular-hydrogrossular. — American Mineralogist 76, 1153-1164.

Sambridge, M., Gerald, J. F., Kovács, I., O’NeIll, H. S. C. \& Hermann, J. 2008: Quantitative absorbance spectroscopy with unpolarized light: Part I. Physical and mathematical development. — American Mineralogist 93, 751-764. https://doi.org/10.2138/am.2008.2657

SÁgi T., Jankovics É. M., Kiss B., Ntaflos T. \& HaRANGi Sz. 2018: Új módszer alkáli bazaltos magmák olivin- és klinopiroxénfrakcionációjának modellezésére. — Földtani Közlöny 148, 273. https://doi.org/10.23928/foldt.kozl.2018.148.3.273

Seghedi, I., Popa, R.-G., PAnaiotu, C. G., SzakÁcs, A. \& PÉcskay, Z. 2016: Short-lived eruptive episodes during the construction of a Na-alkalic basaltic field (Perşani Mountains, SE Transylvania, Romania). — Bulletin of Volcanology 78, 10. https://doi.org/10.1007/ s00445-016-1063-y

SElWAY, K., YI, J. \& Karato, S. I. 2014: Water content of the Tanzanian lithosphere from magnetotelluric data: implications for cratonic growth and stability. — Earth and Planetary Science Letters 388, 175-186 https://doi.org/10.1016/j.epsl.2013.11.024

SElWAy, K., Ford, H. \& KelEMEN, P. 2015: The seismic mid-lithosphere discontinuity. — Earth and Planetary Science Letters 414, 4557. https://doi.org/10.1016/j.epsl.2014.12.029

Sifré, D., Gardés, E., Massuyeau, M., Hashim, L., Hier-Majumder, S. \& Gaillard, F. 2014: Electrical conductivity during incipient melting in the oceanic low-velocity zone. - Nature 509, 8. https://doi.org/10.1038/nature 13245

STALDER, R. 2004: Influence of Fe, Cr and Al on hydrogen incorporation in orthopyroxene. - European Journal of Mineralogy 16, 703711. https://doi.org/10.1127/0935-1221/2004/0016-0703 
Stalder, R. \& Ludwig, T. 2007: OH incorporation in synthetic diopside. - European Journal of Mineralogy 19, 373-380. https://doi.org/10.1127/0935-1221/2007/0019-1721

Stalder, R. \& Skogby, H. 2002: Hydrogen incorporation in enstatite. - European Journal of Mineralogy 14, 1139-1144. https://doi.org/10.1127/0935-1221/2002/0014-113

Stalder, R., Kronz, A. \& Simon, K. 2008: Hydrogen incorporation in enstatite in the system $\mathrm{MgO}-\mathrm{SiO}_{2}-\mathrm{H}_{2} \mathrm{O}-\mathrm{NaCl}$. - Contributions to Mineralogy and Petrology 156, 653. https://doi.org/10.1007/s00410-008-0306-0

Szabó, Á., Berkesi M., ARAdi, L. E. \& SzABÓ, Cs. 2017: Preliminary results of study on fluid inclusions in mantle xenoliths from the Perşani Mountains, Eastern Transylvanian Basin. - ECROFI abstract, 230.

Szabó, Cs., Falus, Gy., Zajacz, Z., Kovács, I. \& Bali, E. 2004: Composition and evolution of lithosphere beneath the CarpathianPannonian Region: a review. — Tectonophysics 393, 119-137. https://doi.org/10.1016/j.tecto.2004.07.031

Thomas, S. M., Koch-Müller, M., Reichart, P., Rhede, D., Thomas, R., Wirth, R. \& Matsyuk, S. 2009: IR calibrations for water determination in olivine, $\mathrm{r}-\mathrm{GeO}_{2}$, and $\mathrm{SiO}_{2}$ polymorphs. — Physics and Chemistry of Minerals 36, 489-509. https://doi.org/ 10.1007/ s00269-009-0295-1

Tondi, R., Achauer, U., LAndes, M., Davi, R. \& Besutiu, L. 2009: Unveiling seismic and density structure beneath the Vrancea seismogenic zone, Romania. — Journal of Geophysical Research 114, B11. http://dx.doi.org/10.1029/2008JB005992

Tóth, A., Dobosi, G., Beard, A., Downes, H., Bali, E. \& Szabó, Cs. 2006: Garnet Pyroxenites from Eastern Transylvanian Basin: an Integrated Textural and Geochemical Study. - Geolines 20, 128-129.

VACAREAnU, R. \& IONESCU, C. 2016: The 1940 Vrancea Earthquake. Issues, Insights and Lessons Learnt. — Springer International Publishing Switzerland, 521 p. http://dx.doi.org/10.1007/978-3-319-29844-3

Vaselli, O., Downes, H., Thirlwall, M., Dobosi, G., Cora-Dossi, H., Seghedi, I., Szakács, A. \& Vannucci, R. 1995: Ultramafic xenoliths in Plio-Pleistocene alkali basalts from the eastern Transylvanian basin: depleted mantle enriched by vein metasomatism. Journal of Petrology 36, 23-53. https://doi.org/10.1093/petrology/36.1.23

Wang, D., MookherJee, M., Xu, Y. \& Karato, S. I. 2006: The effect of water on the electrical conductivity of olivine. - Nature 443, 977-980. https://doi.org/10.1038/nature05256

Wortel, M. J. R. \& Spakman, W. 2000: Subduction and Slab Detachment in the Mediterranean-Carpathian Region. - Science 290, 1910-1917. https://doi.org/10.1126/science.290.5498.1910

Xia, Q. K., Liu, J., Kovacs, I., HaO, Y. T., Li, P., Yang, X. Z., Chen, H. \& Sheng, Y. M. 2019: Water in the upper mantle and deep crust of eastern China: concentration, distribution and implications — National Science Review 6, 125-144. https://doi.org/10.1093/ nsr/nwx016

Yoshino T. \& Katsura T. 2013: Electrical Conductivity of Mantle Minerals: Role of Water in Conductivity Anomalies. Annual Review of Earth and Planetary Sciences 41, 605-628. https://doi.org/10.1146/annurev-earth-050212-124022

Kézirat beérkezett: 2019. 08. 06. 